Article

\title{
Metal Phosphate-Supported Pt Catalysts for CO Oxidation
}

\section{Xiaoshuang Qian, Hongmei Qin, Tao Meng, Yi Lin and Zhen Ma *}

Shanghai Key Laboratory of Atmospheric Particle Pollution and Prevention (LAP ${ }^{3}$ ),

Department of Environmental Science and Engineering, Fudan University, Shanghai 200433, China;

E-Mails: 12210740023@fudan.edu.cn (X.Q.); 12210740024@fudan.edu.cn (H.Q.);

13110740020@fudan.edu.cn (T.M.); 13210740026@fudan.edu.cn (Y.L.)

* Author to whom correspondence should be addressed; E-Mail: zhenma@fudan.edu.cn;

Tel.: +86-21-6564-2997; Fax: +86-21-6564-3597.

Received: 3 November 2014; in revised form: 23 November 2014 / Accepted: 3 December 2014 /

Published: 17 December 2014

\begin{abstract}
Oxides (such as $\mathrm{SiO}_{2}, \mathrm{TiO}_{2}, \mathrm{ZrO}_{2}, \mathrm{Al}_{2} \mathrm{O}_{3}, \mathrm{Fe}_{2} \mathrm{O}_{3}, \mathrm{CeO}_{2}$ ) have often been used to prepare supported $\mathrm{Pt}$ catalysts for $\mathrm{CO}$ oxidation and other reactions, whereas metal phosphate-supported Pt catalysts for CO oxidation were rarely reported. Metal phosphates are a family of metal salts with high thermal stability and acid-base properties. Hydroxyapatite $\left(\mathrm{Ca}_{10}\left(\mathrm{PO}_{4}\right)_{6}(\mathrm{OH})_{2}\right.$, denoted as Ca-P-O here) also has rich hydroxyls. Here we report a series of metal phosphate-supported $\mathrm{Pt}$ (Pt/M-P-O, M= Mg, Al, Ca, Fe, Co, Zn, La) catalysts for $\mathrm{CO}$ oxidation. Pt/Ca-P-O shows the highest activity. Relevant characterization was conducted using $\mathrm{N}_{2}$ adsorption-desorption, inductively coupled plasma (ICP) atomic emission spectroscopy, X-ray diffraction (XRD), transmission electron microscopy (TEM), $\mathrm{CO}_{2}$ temperature-programmed desorption $\left(\mathrm{CO}_{2}-\mathrm{TPD}\right)$, X-ray photoelectron spectroscopy (XPS), and $\mathrm{H}_{2}$ temperature-programmed reduction $\left(\mathrm{H}_{2}-\mathrm{TPR}\right)$. This work furnishes a new catalyst system for $\mathrm{CO}$ oxidation and other possible reactions.
\end{abstract}

Keywords: metal phosphate; hydroxyapatite; Pt catalyst; CO oxidation

\section{Introduction}

Heterogeneous metal catalysts are very useful in synthesizing chemicals, processing fuels, and ablating environmental pollutants [1]. Heterogeneous metal catalysts are often prepared by loading metals (e.g., Pt, Pd, Au, Ag, Rh) onto oxide or carbon supports. Typical oxide supports include $\mathrm{SiO}_{2}$, 
$\mathrm{Al}_{2} \mathrm{O}_{3}, \mathrm{TiO}_{2}, \mathrm{ZrO}_{2}, \mathrm{Fe}_{2} \mathrm{O}_{3}$, and $\mathrm{CeO}_{2}$. These supports, with good thermal stability and high surface areas (usually from 10 to $1000 \mathrm{~m}^{2} / \mathrm{g}$ ) not only provide a platform for dispersing and stabilizing metal nanoparticles, but also render the final catalysts various properties (e.g., acid-base, redox properties). It can be said that these conventional supported metal catalysts are at the heart of heterogeneous catalysis because they are so useful in a variety of reactions and the global market for these catalysts is huge.

Compared with metal oxides and carbons, metal salts have seldom been used in the preparation of supported metal catalysts [2] because many metal salts (e.g., most nitrates, chlorides, and sulfates) are soluble in water and are not thermally stable. These attributes make the preparation of heterogeneous catalysts a daunting task. Fortunately, some metal salts (e.g., metal phosphates) are not soluble in water, and they have good thermal stability. In addition, some metal phosphates are recognized for their acid-base properties [3]. In a classic book written by Tanabe, Misono, Ono, and Hattori, metal phosphates are highlighted as a new family of solid acids showing some promising applications in heterogeneous catalysis [3]. Metal phosphates can be used as catalysts directly, for instance, in the partial oxidation of propane [4], oxidative dehydrogenation of isobutane to isobutene [5-7], oxidative dehydrogenation of ethylbenzene to styrene [8], dehydration of cyclohexanol and 1-methylcyclohexanol [9-11], retro-Prins reaction [12,13], terpene rearrangements [14], alkylation of anisole with alcohols [15], dehydrofluorination of $\mathrm{CF}_{3} \mathrm{CH}_{3}$ into $\mathrm{CF}_{2} \mathrm{CH}_{2}$ [16,17], hydrolysis of $\mathrm{CCl}_{2} \mathrm{~F}_{2}$ [18-20], decomposition of $\mathrm{CF}_{4}$ [21,22], decomposition of $\mathrm{CH}_{2} \mathrm{FCF}_{3}$ [23], decomposition of chlorobenzene [24], decomposition of $\mathrm{SF}_{6}$ [25,26], and hydrolysis of $\mathrm{NF}_{3}$ [27].

Alternatively, metal phosphates can be used as supports to prepare supported metal catalysts. For instance, Lisnyak and co-workers [28] reported that the activity of several Pt and Pd catalysts in catalytic $\mathrm{H}_{2}$ oxidation followed the sequence of $\mathrm{Pt}(\mathrm{Pd}) / \mathrm{NbP}_{2} \mathrm{O}_{7}>\mathrm{Pt}(\mathrm{Pd}) / \mathrm{NbPO}_{5}>\mathrm{Pt}(\mathrm{Pd}) / \mathrm{Al}_{2} \mathrm{O}_{3}$. Johnstone and co-workers [29] investigated the hydrogenation of 1-octene, 1-,3-,4-methylcyclohexenes, and cyclododecene using $\mathrm{Pd}$ and $\mathrm{Pt}$ supported on a variety of metal(IV) phosphates. Miura and co-workers [30] demonstrated that $\mathrm{Pd} / \mathrm{AlPO}_{4}$ showed high activity in the hydrogenation of naphthalene in the presence of CO. Takita and co-workers [31] employed $\mathrm{Pt} / \mathrm{AlPO}_{4}$ and $\mathrm{Pt} / \mathrm{CePO}_{4}-\mathrm{AlPO}_{4}$ for the hydrodechlorination of $\mathrm{CHF}_{2} \mathrm{CClF}_{2}$. More recently, Dai and co-workers [32-34] developed a series of metal phosphate-supported $\mathrm{Au}$ (denoted as $\mathrm{Au} / \mathrm{M}-\mathrm{P}-\mathrm{O}, \mathrm{M}=\mathrm{Fe}, \mathrm{Co}, \mathrm{Y}, \mathrm{La}, \mathrm{Pr}, \mathrm{Nd}, \mathrm{Sm}, \mathrm{Eu}, \mathrm{Ho}, \mathrm{Er}$ ) catalysts and tested their performance in $\mathrm{CO}$ oxidation. Among them, Au/La-P-O and Au/Fe-P-O are representative catalysts, and the nature of active sites and reaction mechanisms were studied in detail $[35,36]$. These supported catalysts provide new opportunities for studying the nature of active sites and reaction mechanism, and for exploring their applications in other reactions.

Hydroxyapatite (HAP, also denoted as Ca-P-O here), with the formula $\mathrm{Ca}_{10}\left(\mathrm{PO}_{4}\right)_{6}(\mathrm{OH})_{2}$, can be used as a catalyst directly [37], for instance, in the conversion of ethanol [38-40], Knoevenagel condensation [41,42], aldol condensation [43], Friedel-Crafts reaction [44], Michael addition [45], and formaldehyde combustion [46]. Heteroatoms, such as $\mathrm{Pb}$ [47], $\mathrm{Pd}$ [48,49], $\mathrm{Cu}$ [50-52], Zn [53], Ni [54], $\mathrm{V}$ [55], $\mathrm{Nb}$ [56], and $\mathrm{Sr}$ [57] can be incorporated into the hydroxyapatite structure via ion-exchange, hydrothermal synthesis, and other methods to tune the catalytic properties.

Hydroxyapatite, with rich hydroxyls, can also be used to support metal nanoparticles. For instance, Scurrell and co-workers prepared Au/HAP for the water-gas shift reaction [58]. Several groups developed Au/HAP catalysts for CO oxidation [33,59-62]. Au/HAP catalysts were also used for the deoxygenation of amides [63], the epoxidation of styrene or cyclohexane [64], the direct tandem 
synthesis of imines or oximes [65], and the removal of organic compounds from aqueous medium via wet peroxidation [66]. Pd/HAP was demonstrated to be a highly efficient and recyclable catalyst for the selective reduction of carbon-carbon double bond in $\alpha, \beta$-unsaturated ketones [67]. Rh/HAP was found to be useful for the water-gas shift reaction [58], the mild racemization of alcohols [68], cis-dihydroxylation and oxidative cleavage of alkenes [69], as well as hydrogen generation from ammonia-borane solution [70]. Ag/HAP was reported to have high activities for the selective oxidation of silanes into silanols using water as an oxidant [71] and selective reduction of $\mathrm{NO}_{\mathrm{x}}$ by propene [72].

Supported Pt catalysts have wide applications in hydrotreating, selective hydrogenation/oxidation, conversion of biomass, ablation of environmental pollutants (e.g., CO, VOCs), and $\mathrm{H}_{2}$ fuel cells [1]. Although there are a number of papers on Pt-catalyzed CO oxidation [73-80], to the best of our knowledge, there was few or almost no report on metal phosphate-supported Pt catalysts for $\mathrm{CO}$ oxidation. There were only a few reports on the catalytic oxidation of $\mathrm{H}_{2}$ on $\mathrm{Pt}(\mathrm{Pd}) / \mathrm{NbP}_{2} \mathrm{O}_{7}$ and $\mathrm{Pt}(\mathrm{Pd}) / \mathrm{NbPO}_{5}$ [28], hydrodechlorination of $\mathrm{CHF}_{2} \mathrm{CClF}_{2}$ on $\mathrm{Pt} / \mathrm{AlPO}_{4}$ and $\mathrm{Pt} / \mathrm{CePO}_{4}-\mathrm{AlPO}_{4}$ [31], and electrocatalysis on $\mathrm{Pt} / \mathrm{AlPO}_{4}$ [81], $\mathrm{Pt} / \mathrm{CePO}_{4}$ [82], and $\mathrm{Pt} / \mathrm{FePO}_{4}[83,84]$ thin film electrodes.

Following our previous work on metal phosphate-supported gold catalysts [33,34], here we developed a series of metal phosphate-supported Pt catalysts and tested their performance in $\mathrm{CO}$ oxidation. Interestingly, Pt/Ca-P-O shows the highest activity. Relevant characterization was conducted using XRD, $\mathrm{N}_{2}$ adsorption-desorption, ICP, TEM, $\mathrm{CO}_{2}$-TPD, XPS, and $\mathrm{H}_{2}-\mathrm{TPR}$.

\section{Results and Discussion}

\subsection{Catalytic Activity of Pt/M-P-O}

Figure 1 shows the $\mathrm{CO}$ conversions on $\mathrm{Pt} / \mathrm{M}-\mathrm{P}-\mathrm{O}(\mathrm{M}=\mathrm{Mg}, \mathrm{Al}, \mathrm{Ca}, \mathrm{Fe}, \mathrm{Co}, \mathrm{Zn}, \mathrm{La})$ catalysts as a function of reaction temperature. These catalysts were prepared by calcining the impregnated $\mathrm{H}_{2} \mathrm{PtCl}_{6} / \mathrm{M}-\mathrm{P}-\mathrm{O}$ precursor at 300 or $500{ }^{\circ} \mathrm{C}$ in a muffle oven, and were pretreated in the catalytic reactor with $4 \% \mathrm{H}_{2}$ (balance $\mathrm{He}$ ) at $300{ }^{\circ} \mathrm{C}$ prior to reaction testing (see the Experimental section for more details). The $\mathrm{H}_{2}$-pretreatment, sometimes adopted in the literature $[73,76,79,80]$ but not always [74,75,77,78], was intended to facilitate the reduction of $\mathrm{Pt}$ and the removal of $\mathrm{Cl}$ from the Cl-containing Pt precursor [85-87]. Our initial experiments show that the pretreatment in $4 \% \mathrm{H}_{2}$ at $300{ }^{\circ} \mathrm{C}$ is beneficial for improving the catalytic activity in some cases, although the calcined catalysts (without further $\mathrm{H}_{2}$ pretreatment) are also active (Figure $\mathrm{S} 1$ in the Supporting Information).

As shown in Figure 1A, the CO conversion increases with the reaction temperature and reaches $100 \%$ at certain temperatures. The $\mathrm{T}_{50}$ (temperature required for $50 \%$ conversion) values of $\mathrm{Pt} / \mathrm{M}-\mathrm{P}-\mathrm{O}$ $(\mathrm{M}=\mathrm{Mg}, \mathrm{Al}, \mathrm{Ca}, \mathrm{Fe}, \mathrm{Co}, \mathrm{Zn}, \mathrm{La})$ calcined at $300{ }^{\circ} \mathrm{C}$ and then pretreated in $4 \% \mathrm{H}_{2}$ at $300{ }^{\circ} \mathrm{C}$ are 123 , $128,92,123,90,130$, and $123{ }^{\circ} \mathrm{C}$, respectively. The temperature window for $100 \%$ conversion on these catalysts is $100-140{ }^{\circ} \mathrm{C}$. Among these catalysts, the most active Pt/Ca-P-O achieves $100 \%$ conversion at $100{ }^{\circ} \mathrm{C}$, whereas the least active Pt/Al-P-O achieves $100 \%$ conversion at $140{ }^{\circ} \mathrm{C}$. 
Figure 1. CO conversions on $\mathrm{Pt} / \mathrm{M}-\mathrm{P}-\mathrm{O}$ catalysts calcined at $300{ }^{\circ} \mathrm{C}(\mathbf{A})$ or $500{ }^{\circ} \mathrm{C}(\mathbf{B})$ and then pretreated in $4 \% \mathrm{H}_{2}$ at $300{ }^{\circ} \mathrm{C}$ prior to reaction testing.
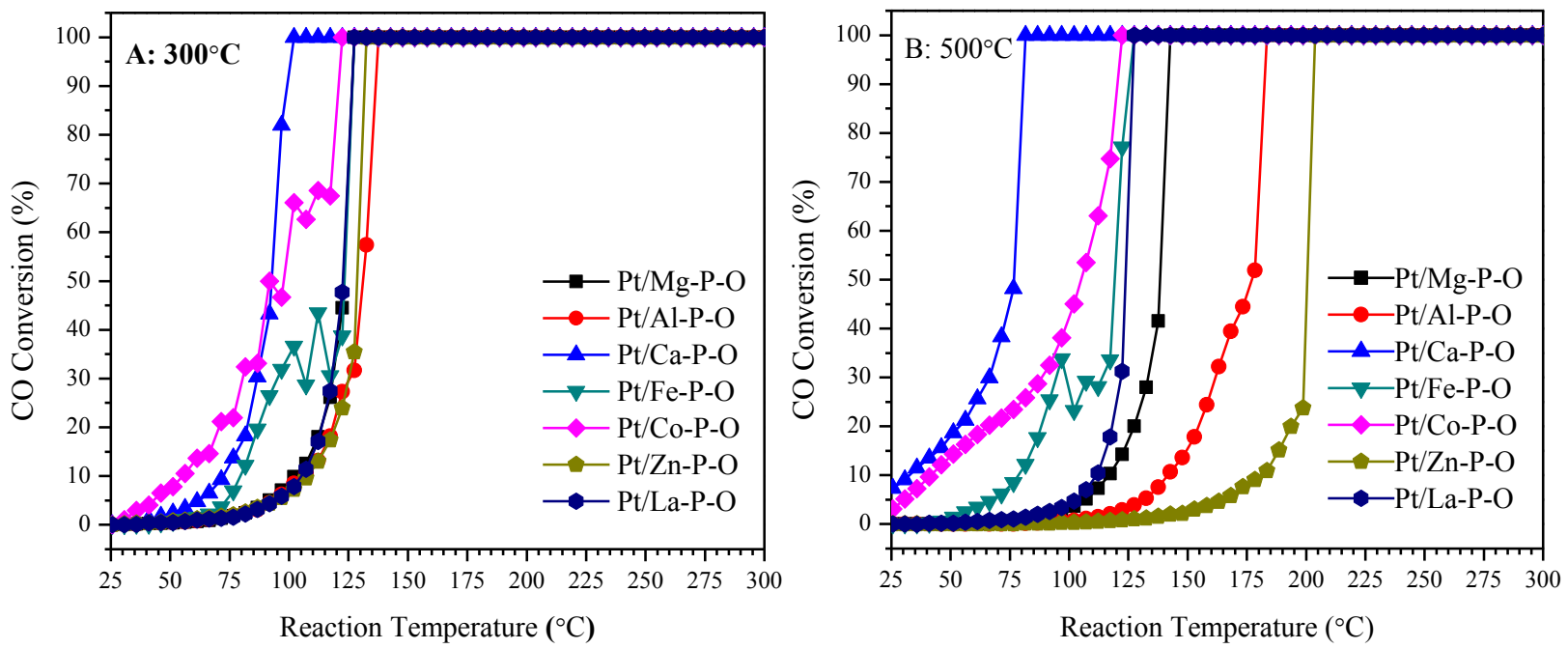

In practical applications, sometimes catalysts have to encounter high-temperature environments, e.g., during catalytic reactions or in catalyst regeneration. Therefore, to see whether the catalysts are still active after high-temperature treatment, the same batch of Pt/M-P-O catalysts were calcined at a higher temperature $\left(500{ }^{\circ} \mathrm{C}\right)$ then pretreated in $4 \% \mathrm{H}_{2}$ at $300{ }^{\circ} \mathrm{C}$ prior to reaction testing. As shown in Figure $1 \mathrm{~B}$, the $\mathrm{T}_{50}$ values of $\mathrm{Pt} / \mathrm{M}-\mathrm{P}-\mathrm{O}(\mathrm{M}=\mathrm{Mg}, \mathrm{Al}, \mathrm{Ca}, \mathrm{Fe}, \mathrm{Co}, \mathrm{Zn}, \mathrm{La})$ calcined at $500{ }^{\circ} \mathrm{C}$ and then pretreated in $4 \% \mathrm{H}_{2}$ at $300{ }^{\circ} \mathrm{C}$ are $140,178,76,120,107,202$, and $123{ }^{\circ} \mathrm{C}$, respectively. The temperature window for $100 \%$ conversion on these catalysts is $80-210{ }^{\circ} \mathrm{C}$, indicating that they are still active after calcination at $500{ }^{\circ} \mathrm{C}$. Note that the $500{ }^{\circ} \mathrm{C}$-calcined $\mathrm{Pt} / \mathrm{Ca}-\mathrm{P}-\mathrm{O}\left(\mathrm{T}_{50}=76{ }^{\circ} \mathrm{C}\right)$ is even more active than the $300{ }^{\circ} \mathrm{C}$-calcined $\mathrm{Pt} / \mathrm{Ca}-\mathrm{P}-\mathrm{O}\left(\mathrm{T}_{50}=90^{\circ} \mathrm{C}\right)$, probably because the removal of more residual $\mathrm{Cl}$ at $500{ }^{\circ} \mathrm{C}$ and the enhanced metal-support interaction upon high-temperature calcination.

The difference in catalytic activity is more obvious for the catalysts calcined at $500{ }^{\circ} \mathrm{C}$ (and subsequently pretreated in $4 \% \mathrm{H}_{2}$ at $300{ }^{\circ} \mathrm{C}$ ), and the activity follows the sequence of $\mathrm{Pt} / \mathrm{Ca}-\mathrm{P}-\mathrm{O}>\mathrm{Pt} / \mathrm{Co}-\mathrm{P}-\mathrm{O}>\mathrm{Pt} / \mathrm{Fe}-\mathrm{P}-\mathrm{O}>\mathrm{Pt} / \mathrm{La}-\mathrm{P}-\mathrm{O}>\mathrm{Pt} / \mathrm{Mg}-\mathrm{P}-\mathrm{O}>\mathrm{Pt} / \mathrm{Al}-\mathrm{P}-\mathrm{O}>\mathrm{Pt} / \mathrm{Zn}-\mathrm{P}-\mathrm{O}$. Because the difference in catalytic activity is large for the catalysts calcined at $500{ }^{\circ} \mathrm{C}$ and large difference in activity may help us find the correlation between catalytic activity and physicochemical properties of catalysts, the following research mainly focused on these catalysts calcined at $500{ }^{\circ} \mathrm{C}$.

\subsection{BET Surface Areas and Pt Contents}

The BET surface areas of Pt/M-P-O (M = Mg, Al, Ca, Fe, Co, Zn, La) catalysts are 24.4, 5.2, 47.1, 8.7, 7.7, $<1$ (below the detection limit), and $71.3 \mathrm{~m}^{2} / \mathrm{g}$, respectively, i.e., Pt/La-P-O shows the highest surface area of $71.3 \mathrm{~m}^{2} / \mathrm{g}, \mathrm{Pt} / \mathrm{Ca}-\mathrm{P}-\mathrm{O}$ has the second largest surface area of $47.1 \mathrm{~m}^{2} / \mathrm{g}$, whereas $\mathrm{Pt} / \mathrm{Zn}-\mathrm{P}-\mathrm{O}$ shows the lowest surface area $\left(<1 \mathrm{~m}^{2} / \mathrm{g}\right)$. One may question the low surface area of Pt/Zn-P-O. We previously prepared $\mathrm{Au} / \mathrm{Zn}-\mathrm{P}-\mathrm{O}$ using $\mathrm{Zn}-\mathrm{P}-\mathrm{O}$ from another commercial supplier (Aldrich), and the surface area of $\mathrm{Au} / \mathrm{Zn}-\mathrm{P}-\mathrm{O}$ was only $3 \mathrm{~m}^{2} / \mathrm{g}$ [33]. The low surface area is consistent with the bulk-like morphology of the support (see Section 2.4) and sharp XRD peaks corresponding to Zn-P-O (Figure 2). 
The Pt content of these catalyst prepared by impregnation (without any washing procedure) was intended to be fixed at $2 \mathrm{wt} \%$. However, some loss of Pt was found to occur during the calcination of the $\mathrm{H}_{2} \mathrm{PtCl}_{6} / \mathrm{M}-\mathrm{P}-\mathrm{O}$ precursors in porcelain crucibles. The inner walls of porcelain crucibles become shinny in some instances, indicating the coating of some metallic Pt to the inner walls. In addition, some drops of $\mathrm{H}_{2} \mathrm{PtCl}_{6}$ solution may adhere to the wall of a beaker during catalyst preparation. The $\mathrm{Pt}$ contents (wt.\%) in Pt/M-P-O (M = Mg, Al, Ca, Fe, Co, Zn, La) calcined at $500{ }^{\circ} \mathrm{C}$ were determined by ICP as $0.49 \%, 1.35 \%, 0.85 \%, 1.42 \%, 1.43 \%, 1.23 \%$, and $1.45 \%$, respectively.

\subsection{XRD Characterization}

Figure 2 summarizes the XRD patterns of Pt/M-P-O catalysts (calcined at 300 or $500{ }^{\circ} \mathrm{C}$ and then pretreated in $4 \% \mathrm{H}_{2}$ at $300{ }^{\circ} \mathrm{C}$ ) collected after catalytic testing. These catalysts are referred to as spent $\mathrm{Pt} / \mathrm{M}-\mathrm{P}-\mathrm{O}$ catalysts. Spent catalysts were characterized herein because they are closer to the working catalysts after being exposed to the reaction ambient. The XRD patterns of M-P-O calcined at $500{ }^{\circ} \mathrm{C}$ and standard M-P-O substances (with the corresponding PDF numbers) are shown for comparison.

Figure 2. XRD patterns of spent Pt/M-P-O catalysts (calcined at 300 or $500{ }^{\circ} \mathrm{C}$, pretreated in $4 \% \mathrm{H}_{2}$ at $300{ }^{\circ} \mathrm{C}$, and tested in $\mathrm{CO}$ oxidation) and M-P-O supports calcined at $500{ }^{\circ} \mathrm{C}$. $\mathrm{M}=\mathrm{Mg}(\mathbf{a}), \mathrm{Al}(\mathbf{b}), \mathrm{Ca}(\mathbf{c}), \mathrm{Fe}(\mathbf{d}), \mathrm{Co}(\mathbf{e}), \mathrm{Zn}(\mathbf{f}), \mathrm{La}(\mathbf{g})$.

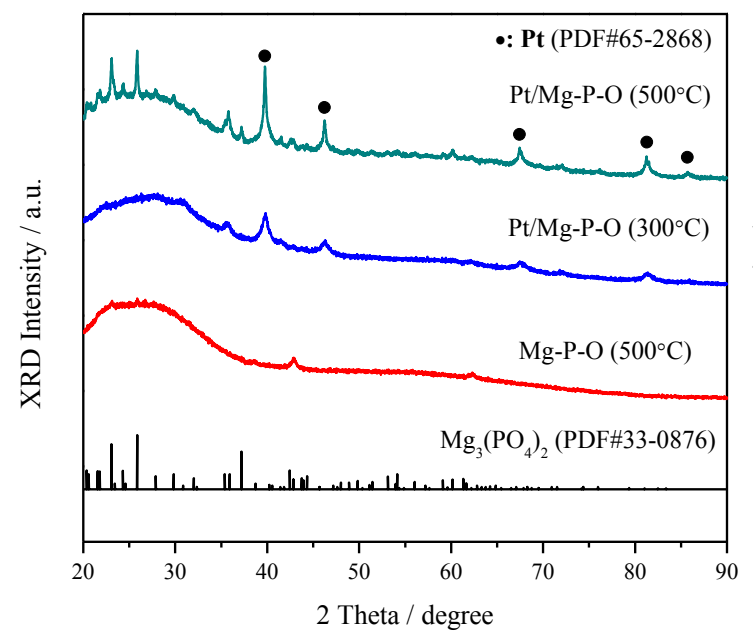

(a)

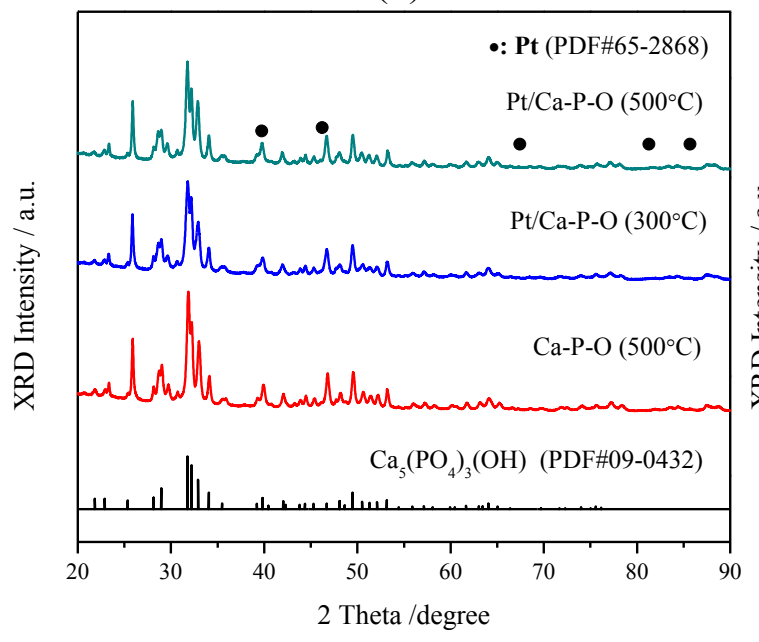

(c)

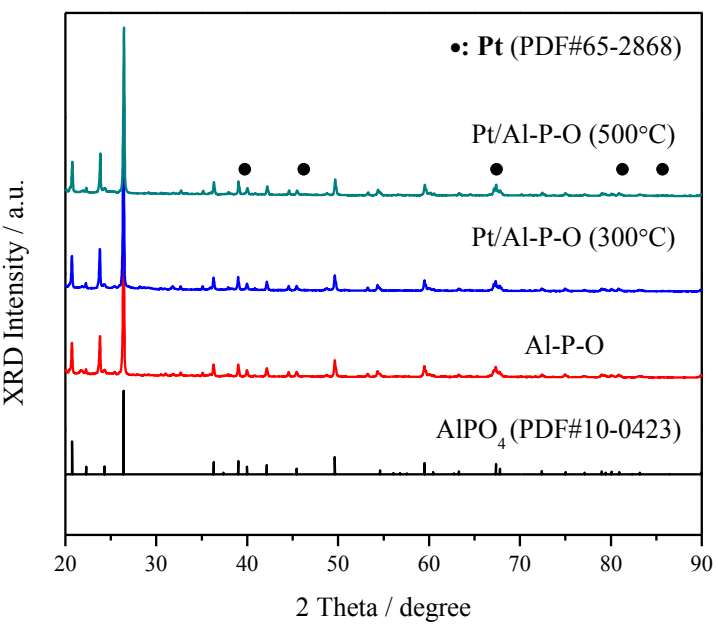

(b)

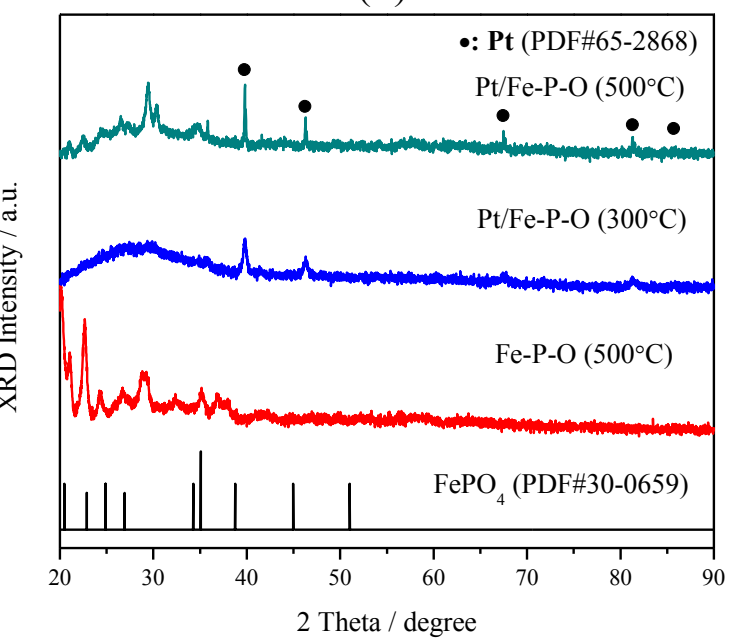

(d) 
Figure 2. Cont.

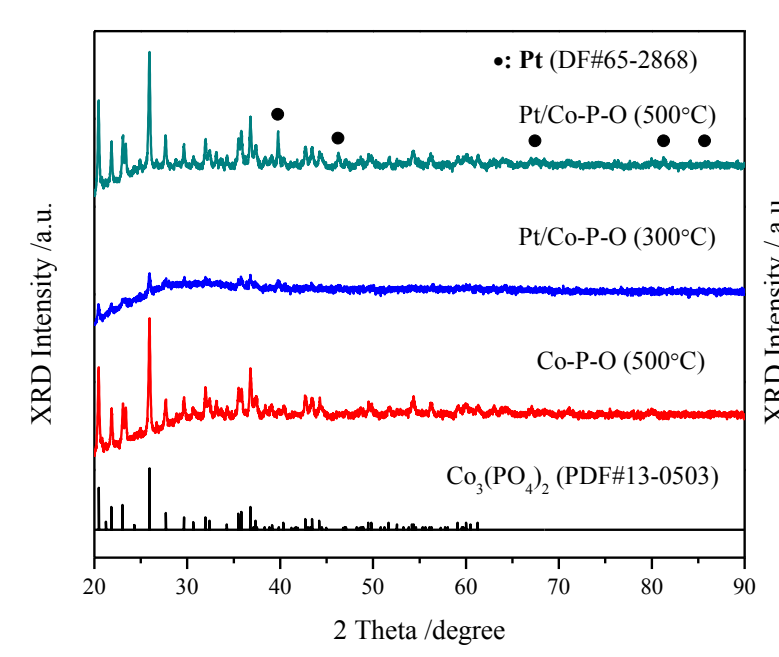

(e)

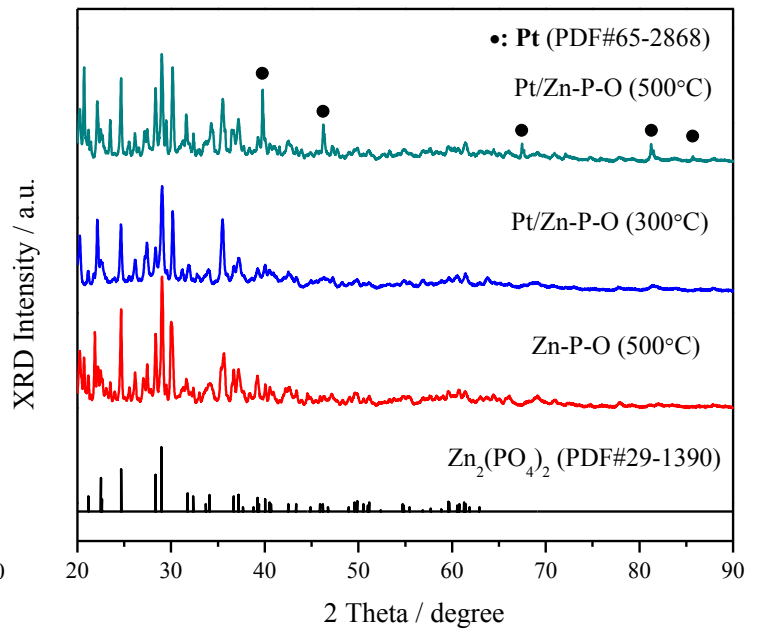

(f)

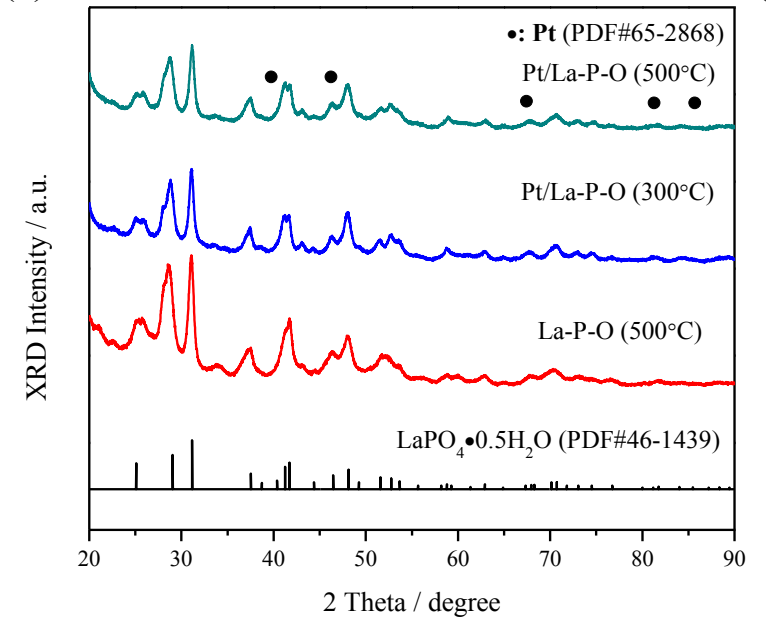

(g)

As shown in Figure 2, Pt/Mg-P-O, Pt/Fe-P-O, Pt/Co-P-O, and Pt/Zn-P-O calcined at $500{ }^{\circ} \mathrm{C}$ (and then pretreated in $4 \% \mathrm{H}_{2}$ at $300{ }^{\circ} \mathrm{C}$ and subjected to reaction testing) exhibit obvious Pt peaks at $2 \theta=39.7^{\circ}, 46.2^{\circ}, 67.4^{\circ}, 81.2^{\circ}$, and $85.6^{\circ}$, indicating the presence of relatively big Pt particles on these supports. The sintering of $\mathrm{Pt}$ nanoparticles is not so obvious for Pt/Mg-P-O, Pt/Fe-P-O, Pt/Co-P-O, and $\mathrm{Pt} / \mathrm{Zn}-\mathrm{P}-\mathrm{O}$ calcined at $300{ }^{\circ} \mathrm{C}$ (and then pretreated in $4 \% \mathrm{H}_{2}$ at $300{ }^{\circ} \mathrm{C}$ and subjected to reaction testing). On the other hand, spent Pt/Al-P-O, Pt/Ca-P-O, and Pt/La-P-O virtually do not show metallic $\mathrm{Pt}$ peaks, regardless of the calcination temperature, indicating that $\mathrm{Pt}$ nanoparticles are highly dispersed.

\subsection{TEM Characterization}

It is well know that the XRD technique has some limitations. For instance, when there are both small and big metal nanoparticles on a support, the XRD peak intensity is biased toward big metal nanoparticles, i.e., the XRD peak becomes too sharp [88]. In order to better see the microscopic picture of the catalysts, the spent $\mathrm{Pt} / \mathrm{M}-\mathrm{P}-\mathrm{O}$ catalysts (calcined at $500{ }^{\circ} \mathrm{C}$, pretreated in $4 \% \mathrm{H}_{2}$ at $300{ }^{\circ} \mathrm{C}$, and then tested in $\mathrm{CO}$ oxidation) were characterized by TEM. Here we classify the catalysts into two categories according to the above-mentioned XRD data that Pt/Mg-P-O, Pt/Fe-P-O, Pt/Co-P-O, and 
$\mathrm{Pt} / \mathrm{Zn}-\mathrm{P}-\mathrm{O}$ calcined at $500{ }^{\circ} \mathrm{C}$ exhibit obvious Pt peaks, whereas Pt/Al-P-O, Pt/Ca-P-O, and Pt/La-P-O virtually do not show Pt peaks (Figure 2).

As shown in Figure 3, Pt nanoparticles with sizes of 2-5 nm are highly dispersed on Mg-P-O (top image), whereas very big Pt particles are occasionally seen (bottom image). This observation explains the existence of sharp Pt peaks on the XRD pattern of spent Pt/Mg-P-O. Clearly, the XRD peak intensity of Pt on Mg-P-O had been biased toward big Pt nanoparticles.

Figure 3. TEM image of spent $\mathrm{Pt} / \mathrm{Mg}-\mathrm{P}-\mathrm{O}$ (calcined at $500{ }^{\circ} \mathrm{C}$, pretreated in $4 \% \mathrm{H}_{2}$ at $300{ }^{\circ} \mathrm{C}$, and tested in $\mathrm{CO}$ oxidation).

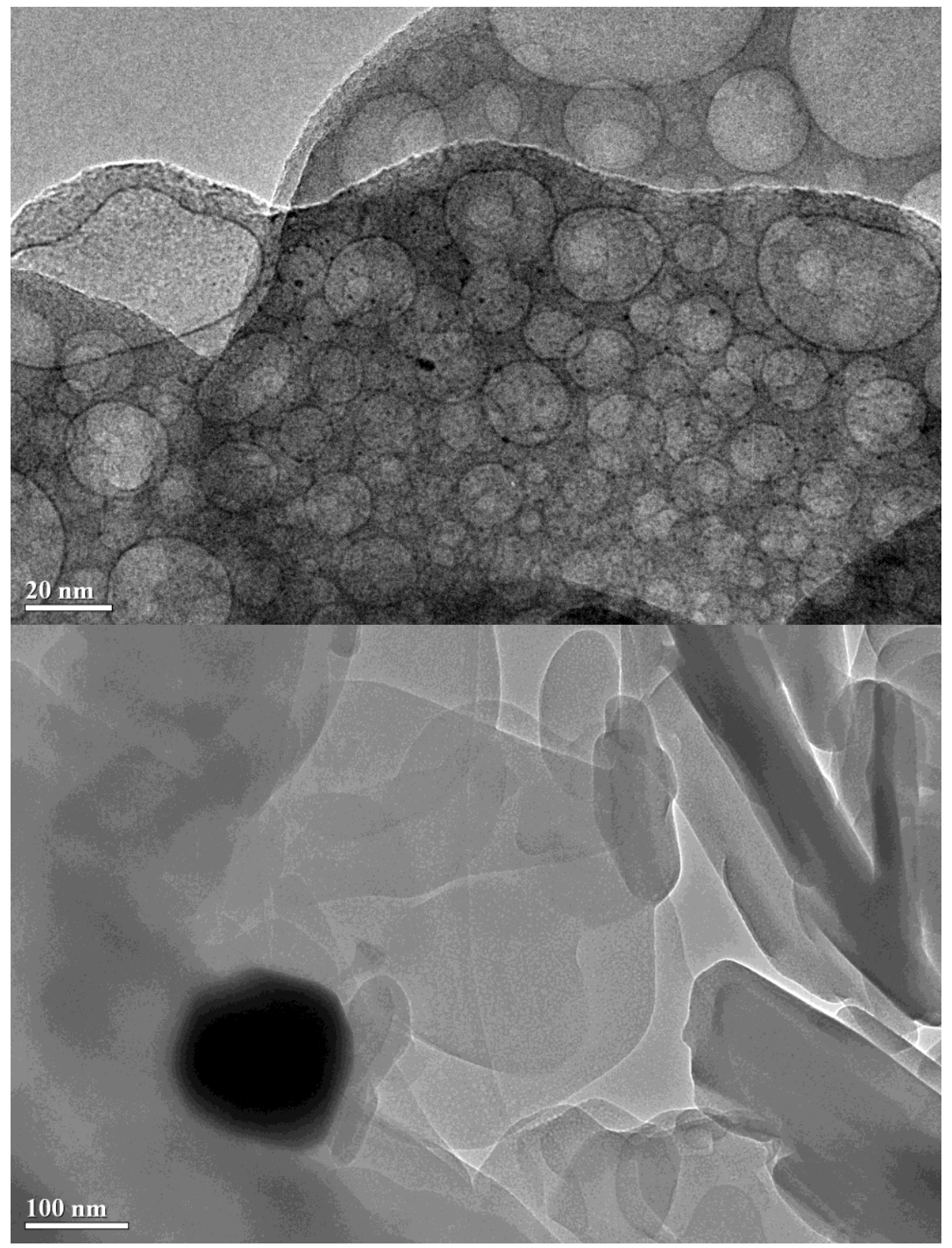

As shown in Figure S2 in the Supporting Information, Pt nanoparticles (2-5 nm in size) are highly dispersed on Fe-P-O. Bigger Pt particles on the order of $10 \mathrm{~nm}$ are also seen. The TEM data again explain the existence of $\mathrm{Pt}$ peaks on the XRD pattern of spent $\mathrm{Pt} / \mathrm{Fe}-\mathrm{P}-\mathrm{O}$. 
Similarly, Pt/Co-P-O has many small Pt nanoparticles (2-5 nm in size) and only a small portion of bigger Pt particles on the order of $10 \mathrm{~nm}$ (Figure S3).

On the other hand, only low-resolution TEM images of Pt/Zn-P-O were collected (Figure S4) because this sample underwent significant structural transformations under the high-energy electron beam when we attempted to record high-resolution TEM images. From the low-resolution TEM images, it is not clear whether this sample has small Pt nanoparticles or not, but big Pt particles can been seen at the edge of the support.

We then turn to the TEM results of spent Pt/Al-P-O, Pt/Ca-P-O, and Pt/La-P-O that virtually do not show XRD peaks of Pt (Figure 2). As shown in Figure 4, Pt/Al-P-O has Pt nanoparticles with sizes in the range of $2-3 \mathrm{~nm}$, consistent with the XRD data showing no $\mathrm{Pt}$ peaks. $\mathrm{Pt} / \mathrm{Ca}-\mathrm{P}-\mathrm{O}$ and $\mathrm{Pt} / \mathrm{La}-\mathrm{P}-\mathrm{O}$ also have small Pt nanoparticles $(2-3 \mathrm{~nm}$ ), whereas big Pt particles are virtually not seen (Figures 5 and S5). Overall, the TEM data and XRD data are complementary: while XRD data show the macroscopic picture of a number of solid powders, TEM data directly show the microscopic picture of the supported Pt particles.

Figure 4. TEM image of spent Pt/Al-P-O (calcined at $500{ }^{\circ} \mathrm{C}$, pretreated in $4 \% \mathrm{H}_{2}$ at $300{ }^{\circ} \mathrm{C}$, and tested in $\mathrm{CO}$ oxidation).

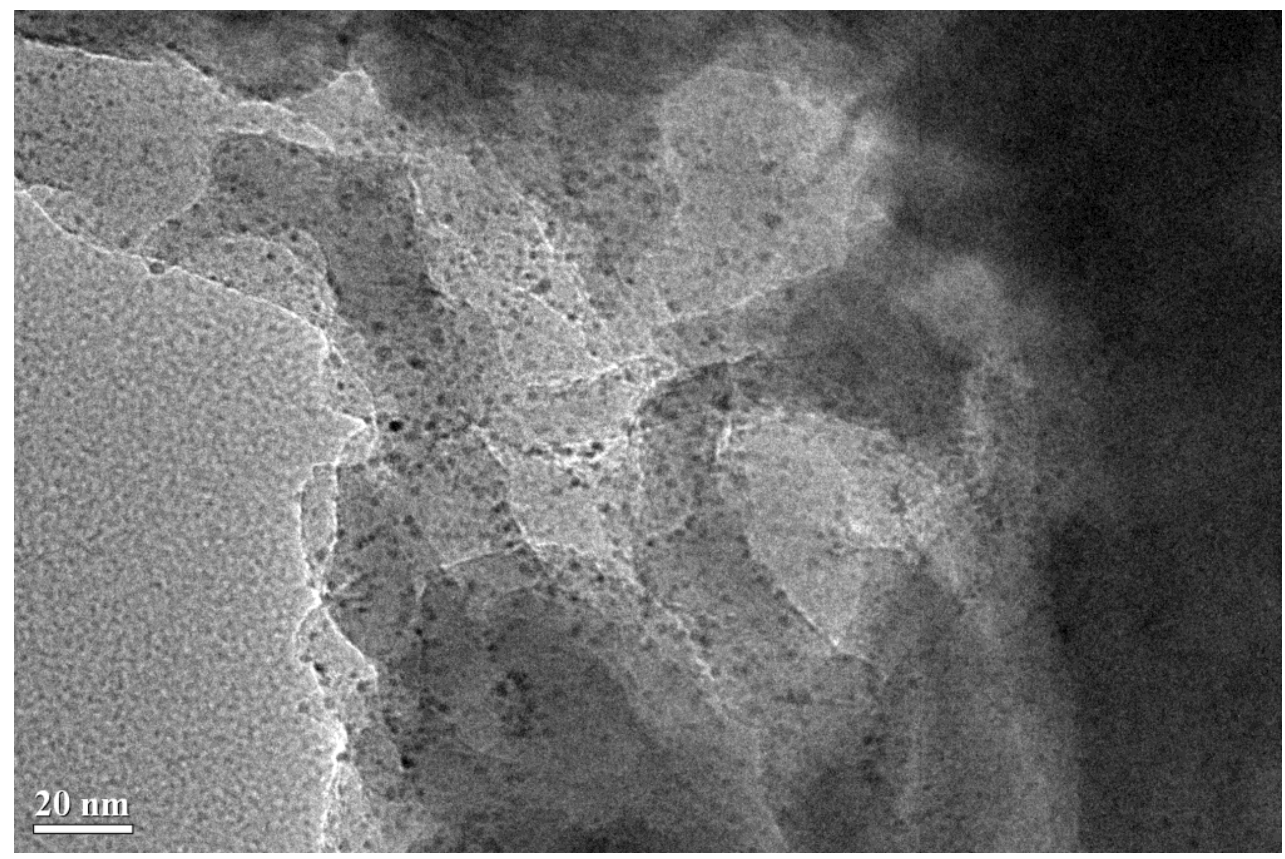


Figure 5. TEM image of spent $\mathrm{Pt} / \mathrm{Ca}-\mathrm{P}-\mathrm{O}$ (calcined at $500{ }^{\circ} \mathrm{C}$, pretreated in $4 \% \mathrm{H}_{2}$ at $300{ }^{\circ} \mathrm{C}$, and tested in $\mathrm{CO}$ oxidation).

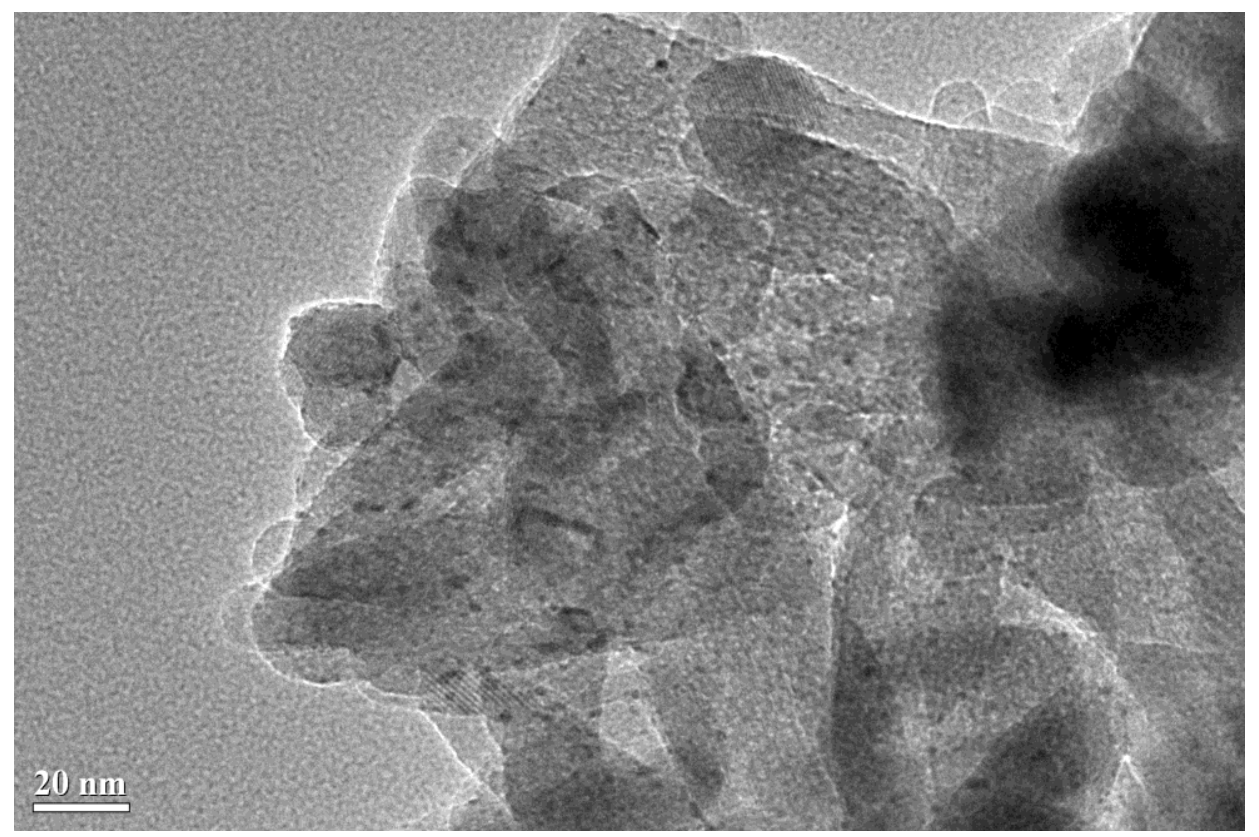

\section{5. $\mathrm{CO}_{2}-\mathrm{TPD}$}

As shown from the catalysis data (Figure 1), Pt/Ca-P-O shows the highest activity. We hypothesize that the surface basicity of the Ca-P-O support [40] plays an important role in the high activity. Therefore, $\mathrm{CO}_{2}$-TPD experiments were conducted. The principle of $\mathrm{CO}_{2}-\mathrm{TPD}$ is that $\mathrm{CO}_{2}$, a weakly acidic molecule, adsorbs onto basic sites of a catalyst at a relatively low temperature (e.g., $50{ }^{\circ} \mathrm{C}$ ), and then desorbs when the temperature ramps. That way, the desorption of $\mathrm{CO}_{2}$ can be used to characterize the basicity of a catalyst. Here, the term "basicity" consists of two parameters: the strength of base (characterized by the peak temperature of $\mathrm{CO}_{2}$ desorption) and the amount of basic sites (characterized by the area of the desorption peak).

As shown in Figure 6, Pt/Mg-P-O, Pt/Al-P-O, Pt/Fe-P-O, Pt/Co-P-O, and Pt/Zn-P-O have very limited desorption of $\mathrm{CO}_{2}$, indicating the lack of basic sites on these catalysts. On the other hand, both $\mathrm{Pt} / \mathrm{Ca}-\mathrm{P}-\mathrm{O}$ and $\mathrm{Pt} / \mathrm{La}-\mathrm{P}-\mathrm{O}$ have obvious peaks corresponding to $\mathrm{CO}_{2}$ desorption. $\mathrm{Pt} / \mathrm{Ca}-\mathrm{P}-\mathrm{O}$ has a main desorption peak centered at $204{ }^{\circ} \mathrm{C}$, whereas Pt/La-P-O has a desorption peak centered at $257{ }^{\circ} \mathrm{C}$. The amounts of basic sites are 76.8 and $147.9 \mu \mathrm{mol} / \mathrm{g}$, respectively. That means that $\mathrm{Pt} / \mathrm{La}-\mathrm{P}-\mathrm{O}$ not only has more basic sites than $\mathrm{Pt} / \mathrm{Ca}-\mathrm{P}-\mathrm{O}$, its basic strength is also stronger than that of $\mathrm{Pt} / \mathrm{Ca}-\mathrm{P}-\mathrm{O}$.

The trend seen in the amount of $\mathrm{CO}_{2}$ desorption is generally consistent with the BET surface area of the catalysts, being 24.4, 5.2, 47.1, 8.7, 7.7, <1 (below detection limit), and $71.3 \mathrm{~m}^{2} / \mathrm{g}$ for Pt/M-P-O $(\mathrm{M}=\mathrm{Mg}, \mathrm{Al}, \mathrm{Ca}, \mathrm{Fe}, \mathrm{Co}, \mathrm{Zn}, \mathrm{La})$ catalysts. Table 1 summarizes some catalysts and characterization results. The correlation between surface area and amount of basic sites is seen in Figure 7. 
Figure 6. $\mathrm{CO}_{2}-\mathrm{TPD}$ profiles of $\mathrm{Pt} / \mathrm{M}-\mathrm{P}-\mathrm{O}$ calcined at $500{ }^{\circ} \mathrm{C}$ and then pretreated in $4 \% \mathrm{H}_{2}$ at $300{ }^{\circ} \mathrm{C}$.

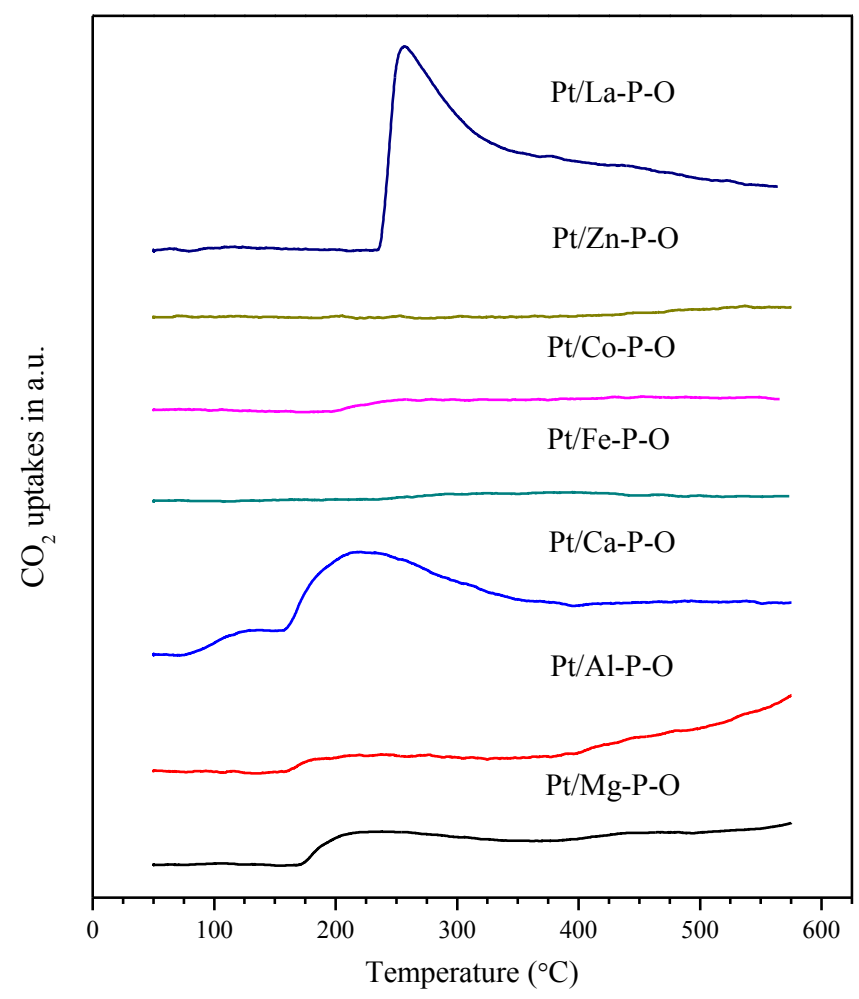

Figure 7. Correlation between the BET surface area and amount of basic sites of Pt/M-P-O catalysts calcined at $500{ }^{\circ} \mathrm{C}$.

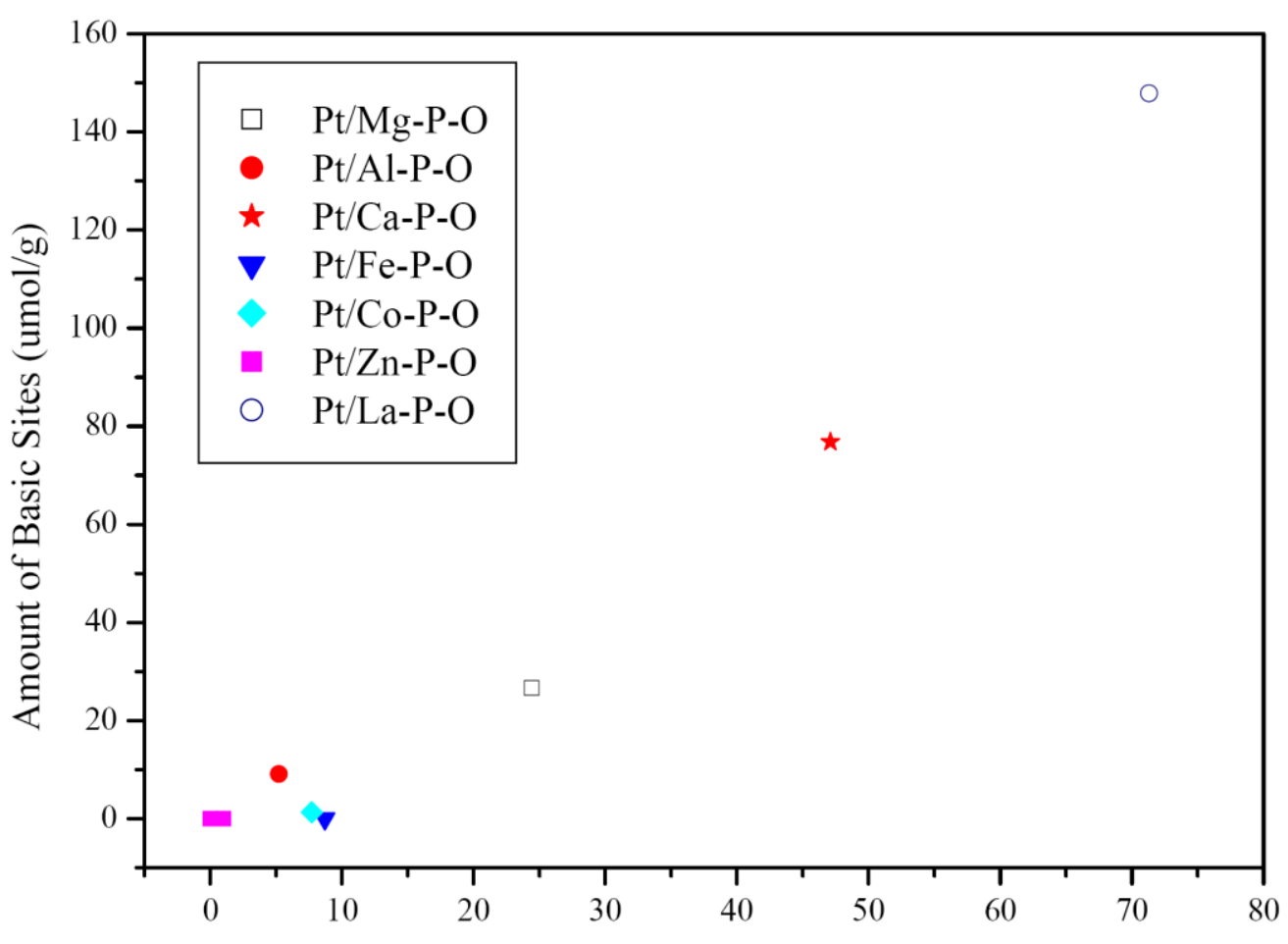

BET Surface Area $\left(\mathrm{m}^{2} / \mathrm{g}\right)$ 
Table 1. T50 values, specific surface areas, Pt contents, average Pt particle sizes, amounts of basic sites, as well as the distribution of surface oxygen species of Pt/M-P-O catalysts. The T50 values refer to those of catalysts calcined at $500{ }^{\circ} \mathrm{C}$ and pretreated in $4 \% \mathrm{H}_{2}$ at $300{ }^{\circ} \mathrm{C}$. The surface areas and $\mathrm{Pt}$ contents refer to those of catalysts calcined at $500{ }^{\circ} \mathrm{C}$. The amounts of basic sites refer to the catalysts calcined at $500{ }^{\circ} \mathrm{C}$ and pretreated in $4 \% \mathrm{H}_{2}$ at $300{ }^{\circ} \mathrm{C}$. The average Pt particle sizes and the distribution of surface oxygen species (OB: bridging oxygen; $\mathrm{O}_{\mathrm{NB}}$ : non-bridging oxygen; $\mathrm{O}_{\mathrm{OH}}$ hydroxyl oxygen) refer to those of catalysts collected after reaction.

\begin{tabular}{|c|c|c|c|c|c|c|c|c|}
\hline \multirow{2}{*}{ Catalyst } & \multirow{2}{*}{$\begin{array}{l}\mathbf{T}_{50} \\
\left({ }^{\circ} \mathbf{C}\right)\end{array}$} & \multirow{2}{*}{$\begin{array}{c}\mathrm{S}_{\mathrm{BET}} \\
\left(\mathrm{m}^{2} / \mathrm{g}\right)\end{array}$} & \multirow{2}{*}{$\begin{array}{c}\text { Pt content } \\
(\%)\end{array}$} & \multirow{2}{*}{$\begin{array}{c}\text { Average Pt particle size } \\
(\mathbf{n m})\end{array}$} & \multirow{2}{*}{$\begin{array}{c}\text { Basic sites } \\
(\mu \mathrm{mol} / \mathrm{g})\end{array}$} & \multicolumn{3}{|c|}{ O1s (\%) } \\
\hline & & & & & & $\mathbf{O}_{\mathbf{B}}$ & $\mathbf{O}_{\mathrm{NB}}$ & $\mathbf{O}_{\mathrm{OH}}$ \\
\hline $\mathrm{Pt} / \mathrm{Mg}-\mathrm{P}-\mathrm{O}$ & 140 & 24.4 & 0.49 & $2-5$, some are very big & 26.6 & 29.8 & 57.0 & 13.2 \\
\hline $\mathrm{Pt} / \mathrm{Al}-\mathrm{P}-\mathrm{O}$ & 178 & 5.2 & 1.35 & $2-3$ & 9.1 & 30.2 & 61.2 & 8.6 \\
\hline $\mathrm{Pt} / \mathrm{Ca}-\mathrm{P}-\mathrm{O}$ & 76 & 47.1 & 0.85 & $2-3$ & 76.8 & 16.6 & 45.5 & 37.9 \\
\hline $\mathrm{Pt} / \mathrm{Fe}-\mathrm{P}-\mathrm{O}$ & 120 & 8.7 & 1.42 & $2-5$, some are big $(10 \mathrm{~nm})$ & 0 & 29.6 & 57.1 & 13.3 \\
\hline $\mathrm{Pt} / \mathrm{Co}-\mathrm{P}-\mathrm{O}$ & 107 & 7.7 & 1.43 & $2-5$, some are big $(10 \mathrm{~nm})$ & 1.3 & 35.1 & 52.1 & 12.8 \\
\hline $\mathrm{Pt} / \mathrm{Zn}-\mathrm{P}-\mathrm{O}$ & 202 & $<1$ & 1.23 & very big & 0 & 20.1 & 66.8 & 13.1 \\
\hline $\mathrm{Pt} / \mathrm{La}-\mathrm{P}-\mathrm{O}$ & 123 & 71.3 & 1.45 & $2-3$ & 147.9 & 32.2 & 59.0 & 8.8 \\
\hline
\end{tabular}


Overall, the $\mathrm{CO}_{2}$-TPD data indicate that although an active Pt/M-P-O catalyst does not have to own basic sites, the most active $\mathrm{Pt} / \mathrm{Ca}-\mathrm{P}-\mathrm{O}$ catalyst has plenty of weak basic sites, which may promote $\mathrm{CO}$ oxidation. On the other hand, although Pt/La-P-O has more basic sites, it is less active than Pt/Ca-P-O, probably because too strong basic sites may make the desorption of $\mathrm{CO}_{2}$ (produced by $\mathrm{CO}$ oxidation) difficult. As a rule of thumb in heterogeneous catalysis, too strong adsorption of the reactant/intermediate/product usually lowers the activity in catalysis [1].

\subsection{XPS Characterization}

It was reported that the presence of hydroxyls on catalyst surfaces can promote CO oxidation [89], whereas Ca-P-O has plenty of hydroxyls [40]. Therefore, we studied the distribution of oxygen species of different catalysts via XPS. The Pt/M-P-O catalysts refer to the ones collected after reaction testing. As we mentioned above, the spent catalysts collected after reaction testing are closer to the working catalysts since they were exposed to the reaction ambient. We will report the XPS data of Pt/Ca-P-O calcined at $500{ }^{\circ} \mathrm{C}, \mathrm{Pt} / \mathrm{Ca}-\mathrm{P}-\mathrm{O}$ calcined at $500{ }^{\circ} \mathrm{C}$ and pretreated in $4 \% \mathrm{H}_{2}$ at $300{ }^{\circ} \mathrm{C}$, as well as spent $\mathrm{Pt} / \mathrm{Ca}-\mathrm{P}-\mathrm{O}$ collected after reaction testing later in this section.

Figure 8 shows the $\mathrm{O} 1 \mathrm{~s}$ spectra in the range of 527-540 eV. There are three kinds of oxygen species. The peak centered at $532.7 \pm 0.2 \mathrm{eV}$ is assigned to non-bridging oxygen (P-O), the peak centered at $534.2 \pm 0.3 \mathrm{eV}$ is assigned to bridging oxygen $(\mathrm{P}-\mathrm{O}-\mathrm{P})$, whereas the peak centered at $531.5 \mathrm{eV}$ is ascribed to hydroxyl oxygen $(-\mathrm{OH})$ [72,90-92]. The original O1s spectra were then deconvoluted according to the assignments. As shown in Figure 8 and Table 1, the percentages of hydroxyl oxygen (among all surface oxygen species) in Pt/M-P-O (M = Mg, Al, Fe, Co, Zn, La) are $13.2 \%, 8.6 \%, 13.3 \%, 12.8 \%, 13.1 \%$, and $8.8 \%$, respectively, whereas that of $\mathrm{Pt} / \mathrm{Ca}-\mathrm{P}-\mathrm{O}$ is $37.9 \%$, consistent with the highest activity of $\mathrm{Pt} / \mathrm{Ca}-\mathrm{P}-\mathrm{O}$.

Figure 8. O1s XPS data of Pt/M-P-O catalysts collected after reaction testing. $\mathrm{M}=\mathrm{Mg}$ (a), $\mathrm{Al}$ (b), $\mathrm{Fe}(\mathbf{c}), \mathrm{Co}(\mathbf{d}), \mathrm{Zn}(\mathbf{e}), \mathrm{La}(\mathbf{f})$.

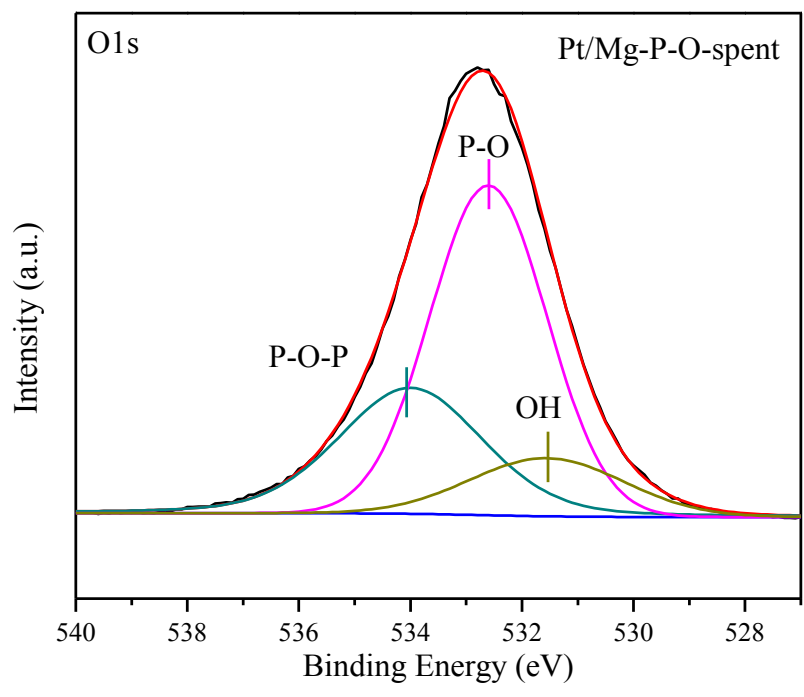

(a)

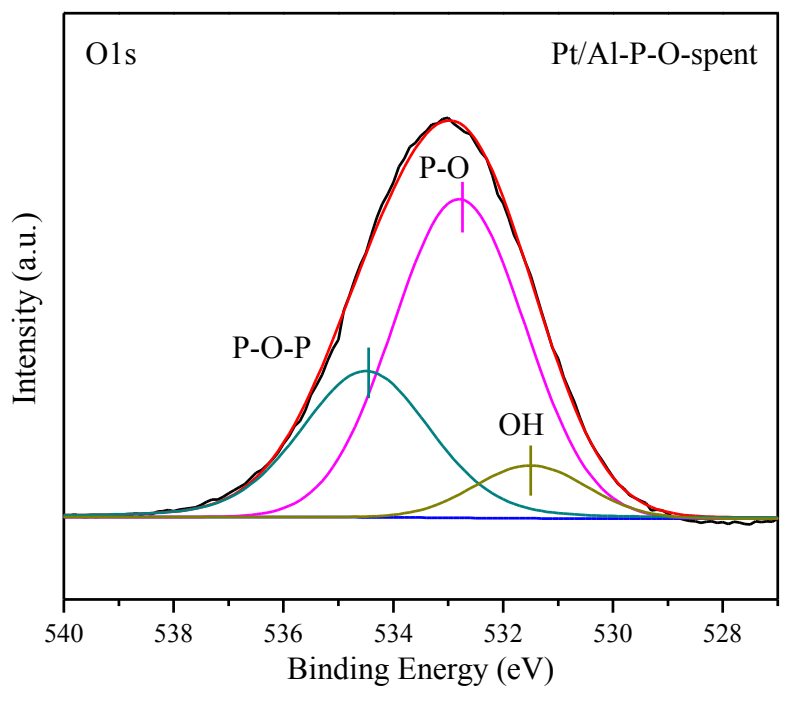

(b) 
Figure 8. Cont.

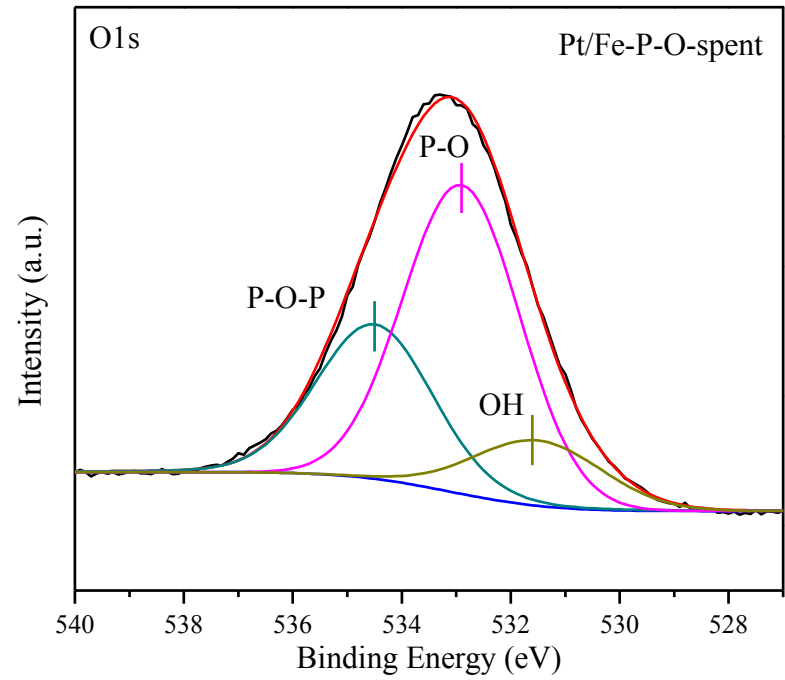

(c)

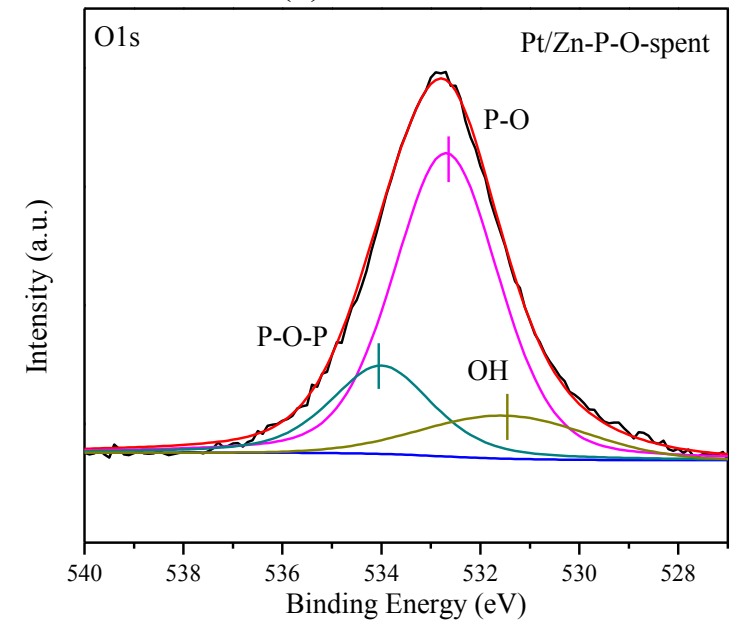

(e)

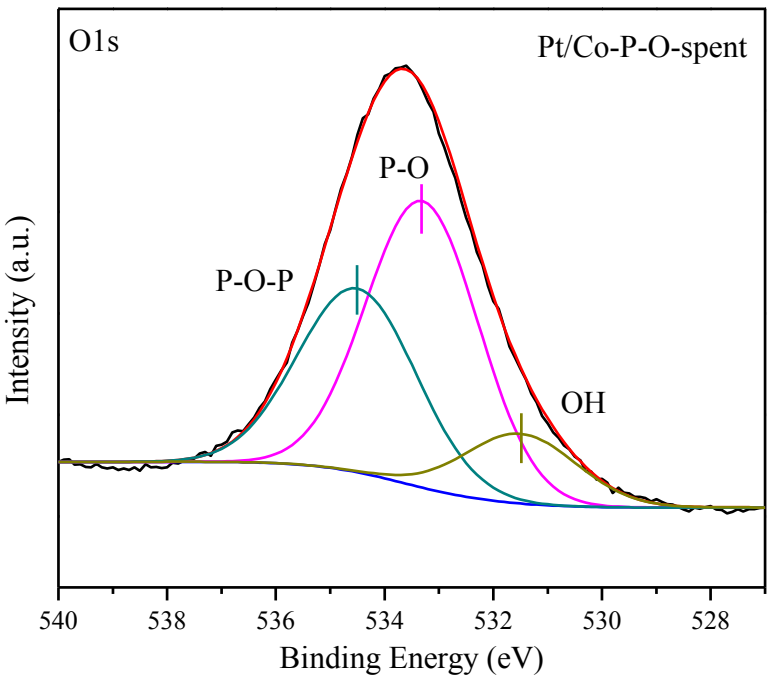

(d)

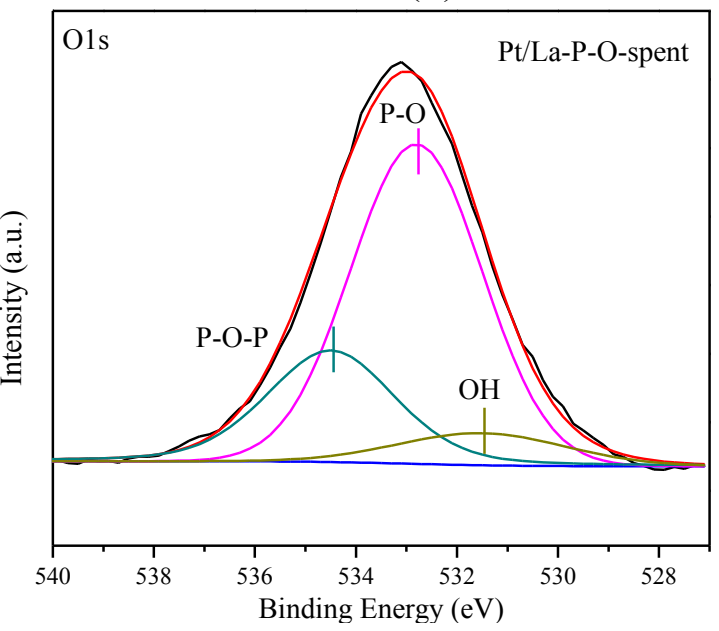

(f)

To provide more information on the nature of key elements of the most active catalyst and know more about what happens in various stages of treatment/reaction, $\mathrm{Pt} / \mathrm{Ca}-\mathrm{P}-\mathrm{O}$ collected at several stages were characterized by XPS. "Pt/Ca-P-O-calcined" refers to the catalyst calcined at $500{ }^{\circ} \mathrm{C}$, without further pretreatment in $4 \% \mathrm{H}_{2}$. "Pt/Ca-P-O-pre $\mathrm{H}_{2}$ " refers to the catalyst calcinated at $500{ }^{\circ} \mathrm{C}$ and pretreated in $4 \% \mathrm{H}_{2}$ at $300{ }^{\circ} \mathrm{C}$, without undergoing catalytic reaction. "Pt/Ca-P-O-spent" refers to the catalyst collected after reaction testing.

As shown in Figure 9 and Table 2, the Pt in "Pt/Ca-P-O-calcined" mainly exists in the form of $\mathrm{Pt}^{4+}$, which represents $90.8 \%$ of all $\mathrm{Pt}$ species $\left(\mathrm{Pt}^{0}, \mathrm{Pt}^{2+}, \mathrm{Pt}^{4+}\right)$. This is understandable, considering that the decomposition of $\mathrm{H}_{2} \mathrm{PtCl}_{6}$ occurs under air at $500{ }^{\circ} \mathrm{C}$. Upon reduction in $4 \% \mathrm{H}_{2}$ at $300{ }^{\circ} \mathrm{C}$, the $\mathrm{Pt}$ species in the catalyst are mainly $\mathrm{Pt}^{0}(33.8 \%)$ and $\mathrm{Pt}^{2+}(49.5 \%)$. Certainly, the $4 \% \mathrm{H}_{2}$ is not enough to fully reduce $\mathrm{Pt}^{4+}$ at $300{ }^{\circ} \mathrm{C}$. For the catalyst collected after $\mathrm{CO}$ oxidation, the relative percentages of $\mathrm{Pt}^{0}$ and $\mathrm{Pt}^{2+}$ change to $27.2 \%$ and $51.7 \%$, respectively, indicating the oxidation of a small portion of $\mathrm{Pt}^{0}$ during the course of the reaction. Therefore, the working catalyst contains both $\mathrm{Pt}^{0}$ and $\mathrm{Pt}^{2+}$, together with a small portion of $\mathrm{Pt}^{4+}$. 
Figure 9. Pt4f XPS data of Pt/Ca-P-O calcined at $500{ }^{\circ} \mathrm{C}$ (a); Pt/Ca-P-O calcined at $500{ }^{\circ} \mathrm{C}$ and then pretreated in $4 \% \mathrm{H}_{2}$ at $300{ }^{\circ} \mathrm{C}(\mathbf{b})$; and $\mathrm{Pt} / \mathrm{Ca}-\mathrm{P}-\mathrm{O}$ collected after reaction $(\mathbf{c})$.

(a)

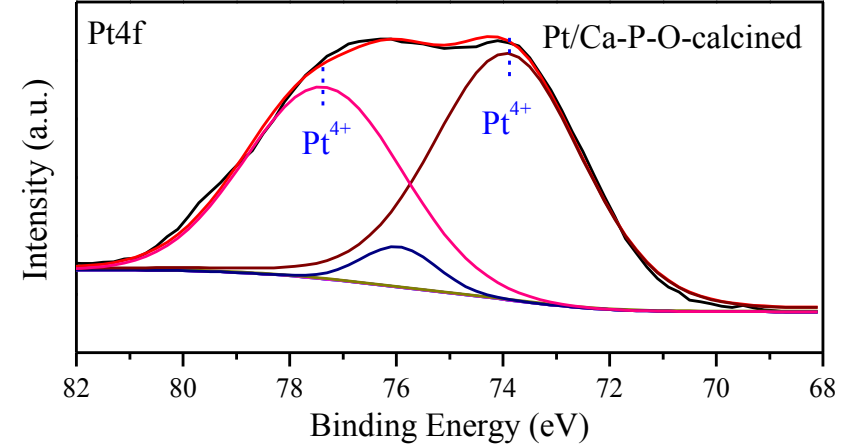

(b)

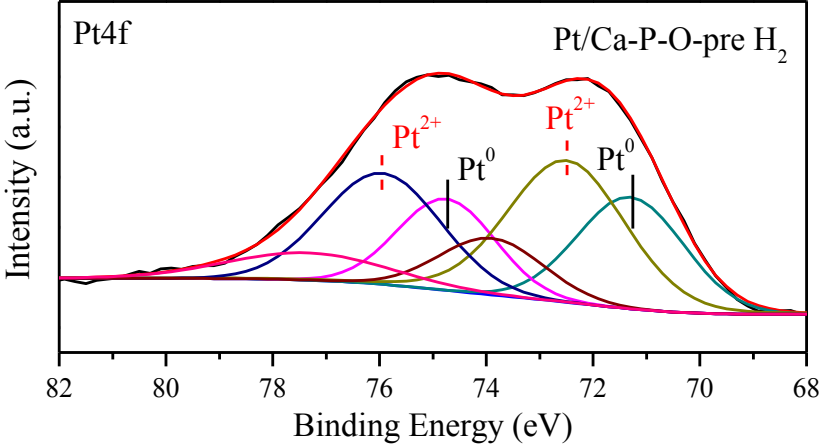

(c)

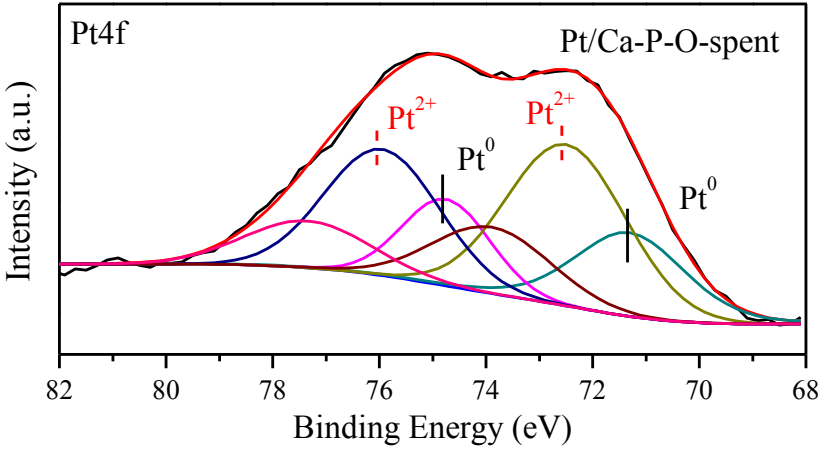

Table 2. Results from XPS analysis of Pt/Ca-P-O catalysts.

\begin{tabular}{ccccccc}
\hline Sample & $\mathbf{C a} / \mathbf{P}$ & $\mathbf{P t}^{\mathbf{0}} / \mathbf{P t}_{\text {total }}$ & $\mathbf{P t}^{\mathbf{2}} / \mathbf{P t}_{\text {total }}$ & $\mathbf{P t}^{\mathbf{4 +}} / \mathbf{P t} t_{\text {total }}$ & $\mathbf{O}_{\mathbf{O H}} \mathbf{( \% )}$ & $\mathbf{C l} / \mathbf{P t}$ \\
\hline Pt/Ca-P-O-calcined & 1.29 & 0 & 0.092 & 0.908 & 30.1 & 1.39 \\
Pt/Ca-P-O-pre H $\mathrm{H}_{2}$ & 1.29 & 0.338 & 0.495 & 0.167 & 46.1 & 1.26 \\
Pt/Ca-P-O-spent & 1.38 & 0.272 & 0.517 & 0.211 & 37.9 & 1.22 \\
\hline
\end{tabular}

Figure 10 shows the XPS data for O1s peaks. The broad O1s peak can be deconvoluted into three peaks centered at 531.5, 532.6, and $534.5 \mathrm{eV}$, corresponding to hydroxyl oxygen $(-\mathrm{OH})$, non-bridging oxygen (P-O), and bridging oxygen (P-O-P). As shown in Figure 10 and Table 2, the percentage of hydroxyl oxygen among all oxygen species in "Pt/Ca-P-O-calcined" is $30.1 \%$. After the catalyst was pretreated in $4 \% \mathrm{H}_{2}$ at $300{ }^{\circ} \mathrm{C}$, the value increases to $46.1 \%$. This finding is interesting, in that the $\mathrm{H}_{2}$ treatment at $300{ }^{\circ} \mathrm{C}$ can replenish some hydroxyls. After reaction testing, the value decreases slightly to $37.9 \%$.

Since the catalysts were prepared by impregnating $\mathrm{H}_{2} \mathrm{PtCl}_{6}$ onto supports, the residual $\mathrm{Cl}$ should be examined. According to our XPS analysis, the surface $\mathrm{Cl} / \mathrm{Pt}$ ratio for "Pt/Ca-P-O-calcined" is 1.39. 
The number is not negligible; residual $\mathrm{Cl}$ may adsorb on some basic sites of $\mathrm{Ca}-\mathrm{P}-\mathrm{O}$. The $\mathrm{Cl} / \mathrm{Pt}$ ratio decreases slightly to 1.26 after $\mathrm{H}_{2}$ treatment, and remains at 1.22 after undergoing $\mathrm{CO}$ oxidation. The decrease in the $\mathrm{Cl}$ content after $\mathrm{H}_{2}$ treatment may account for the higher activity of $\mathrm{Pt} / \mathrm{Ca}-\mathrm{P}-\mathrm{O}$ pretreated in $4 \% \mathrm{H}_{2}$ (Figure $\mathrm{S} 1$ ).

Figure 10. O1s XPS data of Pt/Ca-P-O-calcined (a), Pt/Ca-P-O-pre $\mathrm{H}_{2}$ (b), and $\mathrm{Pt} / \mathrm{Ca}-\mathrm{P}-\mathrm{O}-$ spent (c).

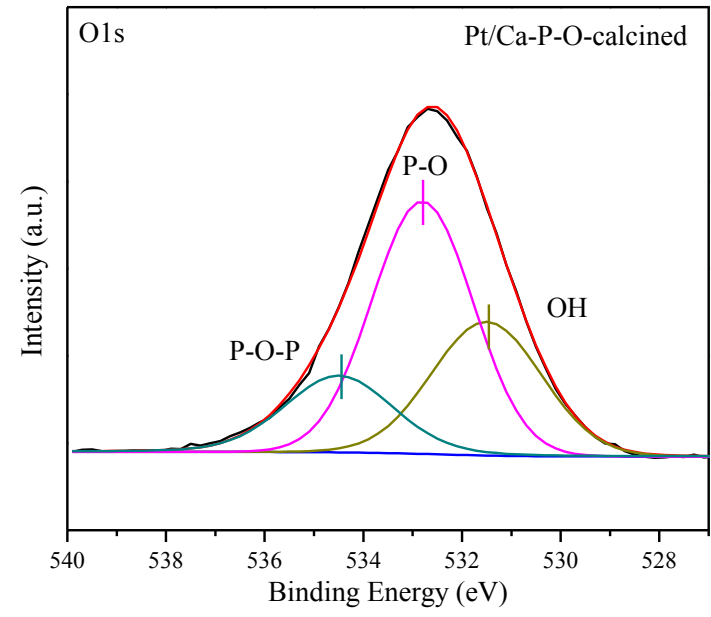

(a)

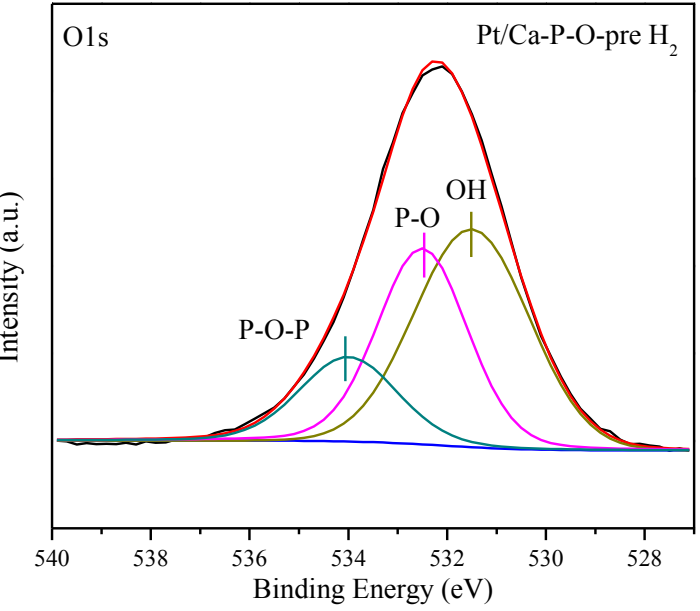

(b)

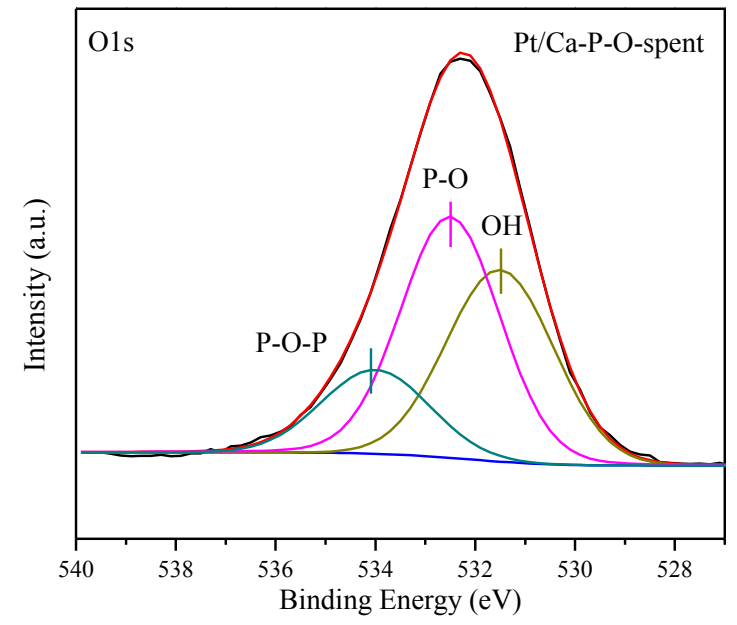

(c)

\subsection{Discussion}

Much effort has been made in the literature to develop new catalysts with various compositions and tailored structures/morphologies, study the effect of preparation parameters, characterize the catalysts, and explore the application of the catalysts in various reactions. Most supported metal catalysts are composed of metals and solid supports. The solid supports are usually oxides (e.g., $\mathrm{SiO}_{2}, \mathrm{Al}_{2} \mathrm{O}_{3}, \mathrm{TiO}_{2}$, $\mathrm{ZrO}_{2}, \mathrm{Fe}_{2} \mathrm{O}_{3}, \mathrm{CeO}_{2}$ ) and carbons, but metal salts have been much less frequently used as supports. In the literature, some metal carbonates, phosphates, and sulfates have been used as supports to load metals [2]. From the examples on the catalytic applications of metal phosphate-based catalysts cited in the Introduction section [4-72,81-83], one can see that research in this direction is interesting, because 
different metal phosphates have different acid-base properties that may have an effect on their catalytic performance.

To put our current work in perspective, it should be mentioned that Dai and co-workers [33,34] have previously developed a series of metal phosphate-supported Au catalysts for $\mathrm{CO}$ oxidation. The key point of that work is that some Au/M-P-O catalysts can also be active for $\mathrm{CO}$ oxidation, although most $\mathrm{Au}$ catalysts reported in the literature are composed of $\mathrm{Au}$ and oxides or carbon. Here we again developed a series of metal phosphate-supported Pt catalysts for $\mathrm{CO}$ oxidation. Although $\mathrm{Pt}$ catalysts are generally less active than $\mathrm{Au}$ catalysts (for instance, $\mathrm{Au} / \mathrm{Ca}-\mathrm{P}-\mathrm{O}$ calcined at $500{ }^{\circ} \mathrm{C}$ reached complete $\mathrm{CO}$ conversion at $40{ }^{\circ} \mathrm{C}$ whereas $\mathrm{Pt} / \mathrm{Ca}-\mathrm{P}-\mathrm{O}$ reached $100 \% \mathrm{CO}$ conversion at $140{ }^{\circ} \mathrm{C}$ ), the objective of our current work is not just to focus on catalytic activity, but to develop a series of phosphate-supported $\mathrm{Pt}$ catalysts that may be useful for $\mathrm{CO}$ oxidation and other reactions that may take advantage of the different acid-base properties of the metal phosphate supports.

Our current research has shown that Pt/M-P-O catalysts calcined at $300{ }^{\circ} \mathrm{C}$ and reduced in $4 \% \mathrm{H}_{2}$ at $300{ }^{\circ} \mathrm{C}$ are active for $\mathrm{CO}$ oxidation (Figure 1). The $\mathrm{T}_{50}$ values of $\mathrm{Pt} / \mathrm{M}-\mathrm{P}-\mathrm{O}(\mathrm{M}=\mathrm{Mg}, \mathrm{Al}, \mathrm{Ca}, \mathrm{Fe}, \mathrm{Co}$, $\mathrm{Zn}, \mathrm{La})$ calcined at $300{ }^{\circ} \mathrm{C}$ and then pretreated in $4 \% \mathrm{H}_{2}$ at $300{ }^{\circ} \mathrm{C}$ are $123,128,92,123,90,130$, and $123{ }^{\circ} \mathrm{C}$, respectively. The difference of catalytic activities becomes more obvious when these catalysts were calcined at $500{ }^{\circ} \mathrm{C}$. The $\mathrm{T}_{50}$ values of Pt/M-P-O $(\mathrm{M}=\mathrm{Mg}, \mathrm{Al}, \mathrm{Ca}, \mathrm{Fe}, \mathrm{Co}, \mathrm{Zn}, \mathrm{La})$ calcined at $500{ }^{\circ} \mathrm{C}$ and then pretreated in $4 \% \mathrm{H}_{2}$ at $300{ }^{\circ} \mathrm{C}$ are $140,178,76,120,107,202$, and $123{ }^{\circ} \mathrm{C}$, respectively. The activity follows the sequence of $\mathrm{Pt} / \mathrm{Ca}-\mathrm{P}-\mathrm{O}>\mathrm{Pt} / \mathrm{Co}-\mathrm{P}-\mathrm{O}>\mathrm{Pt} / \mathrm{Fe}-\mathrm{P}-\mathrm{O}>\mathrm{Pt} / \mathrm{La}-\mathrm{P}-\mathrm{O}>\mathrm{Pt} / \mathrm{Mg}-\mathrm{P}-\mathrm{O}>$ $\mathrm{Pt} / \mathrm{Al}-\mathrm{P}-\mathrm{O}>\mathrm{Pt} / \mathrm{Zn}-\mathrm{P}-\mathrm{O}$. As shown in Figure 2, the calcination at $500{ }^{\circ} \mathrm{C}$ can lead to the sintering of $\mathrm{Pt}$ nanoparticles on some supports (i.e., Mg-P-O, Fe-P-O, Co-P-O, and Zn-P-O). This can explain the decrease in activity for some catalysts calcined at $500{ }^{\circ} \mathrm{C}$. In particular, $\mathrm{Pt} / \mathrm{Zn}-\mathrm{P}-\mathrm{O}$ undergoes significant loss of activity upon calcination at $500^{\circ} \mathrm{C}$, probably due to the sintering of $\mathrm{Pt}$ nanoparticles.

Because the difference in catalytic activity is more obvious for the catalysts calcined at $500{ }^{\circ} \mathrm{C}$, most of the characterization was focused on the catalysts calcined at $500{ }^{\circ} \mathrm{C}$. XRD data show the presence of sharp Pt peaks for Pt/Mg-P-O, Pt/Fe-P-O, Pt/Co-P-O, and Pt/Zn-P-O calcined at $500{ }^{\circ} \mathrm{C}$. TEM characterization indeed shows the presence of big Pt particles on the former three catalysts. The high-resolution TEM images of Pt/Zn-P-O cannot be obtained due to the transformation of the sample under high-energy electron beam. However, TEM characterization also shows the presence of a significant portion of small Pt particles on the former three catalysts. The TEM data are consistent with the XRD data.

XRD data show that there are no Pt peaks for Pt/Al-P-O, Pt/Ca-P-O, and Pt/La-P-O calcined at $500{ }^{\circ} \mathrm{C}$, indicating the high dispersion of Pt nanoparticles on these supports. Our TEM data provide evidence for this conclusion. These highly dispersed Pt nanoparticles should be responsible for the catalytic activities. Note that the $\mathrm{Pt}$ loading on $\mathrm{Pt} / \mathrm{Ca}-\mathrm{P}-\mathrm{O}(0.85 \%)$ is even lower than that on Pt/Al-P-O (1.35\%), and the Pt particle sizes on both catalysts are similar, but $\mathrm{Pt} / \mathrm{Ca}-\mathrm{P}-\mathrm{O}$ calcined at $500{ }^{\circ} \mathrm{C}$ is much more active than Pt/Al-P-O. Therefore, support effect plays an important role in influencing the catalytic activity.

The roles of solid supports are to disperse the active component (e.g., metal nanoparticles) and bestow surface areas, thermal stability, and mechanical strength to the prepared catalysts [1]. Some supports also have acid/base and/or redox properties, and therefore can facilitate certain catalytic reactions. One classical example is the isomerization of an $n$-paraffin to an isoparaffin over 
$\mathrm{Pt} / \mathrm{SiO}_{2}-\mathrm{Al}_{2} \mathrm{O}_{3}$ [93]. While $\mathrm{Pt}$ is effective for the dehydrogenation and hydrogenation steps, the acidic support $\left(\mathrm{SiO}_{2}-\mathrm{Al}_{2} \mathrm{O}_{3}\right)$ is responsible for the isomerization step.

For oxidation reactions such as $\mathrm{CO}$ oxidation, the nature of the oxide support is important. Some non-reducible oxides (e.g., $\mathrm{SiO}_{2}, \mathrm{Al}_{2} \mathrm{O}_{3}$ ) are classified into "inert" supports because they cannot supply oxygen for $\mathrm{CO}$ oxidation, whereas some reducible oxides (e.g., $\mathrm{TiO}_{2}, \mathrm{Fe}_{2} \mathrm{O}_{3}, \mathrm{CeO}_{2}$ ) are classified into "active" supports because they can supply lattice oxygen to react with $\mathrm{CO}$, leaving defects that are then replenished by a separate reaction with oxygen from the gas phase [94,95]. In our case, $\mathrm{H}_{2}-\mathrm{TPR}$ data indicate that Mg-P-O, Al-P-O, Ca-P-O, Zn-P-O, and La-P-O supports are non-reducible, whereas Fe-P-O and Co-P-O supports are reducible (Figure S6). Therefore, although a reducible support may help the catalyst achieve high activity, this is not a prerequisite; the most active catalyst $\mathrm{Pt} / \mathrm{Ca}-\mathrm{P}-\mathrm{O}$ has a non-reducible support.

Note that Ca-P-O (hydroxypatite) has rich basic sites and hydroxyls. Indeed, our $\mathrm{CO}_{2}-\mathrm{TPD}$ data indicate the presence of plenty of basic sites on Pt/Ca-P-O (Figure 6), and our XPS data indicate the presence of significantly more hydroxyls on Pt/Ca-P-O than on other catalysts (Table 1, Figures 8 and 10). In the literature, both basic sites [96,97] and surface hydroxyls [40] were reported to facilitate catalytic $\mathrm{CO}$ oxidation. For instance, Lee et al. [96] found the addition of $\mathrm{K}_{2} \mathrm{O}$ or $\mathrm{Na}_{2} \mathrm{O}$ into $\mathrm{Pt} / \mathrm{Al}_{2} \mathrm{O}_{3}$ can increase the number of basic sites thus increasing the activity in $\mathrm{CO}$ oxidation. Liu et al. [97] reported that the presence of basic sites on supports of Pd catalysts can facilitate the charge transfer in the catalyst and enhance the adsorption of $\mathrm{CO}$, thus increasing the activity in $\mathrm{CO}$ oxidation. Chen et al. [89] demonstrated the presence of hydroxyls on $\mathrm{Pt} / \mathrm{Fe}(\mathrm{OH})_{\mathrm{x}}$ by XPS, and proposed, based on density function theory (DFT) calculations, that surface hydroxyls can combine with $\mathrm{CO}$ to form $-\mathrm{COOH}$ intermediate which then decomposes to $\mathrm{CO}_{2}$ and interfacial vacancies. The vacancies are prone to adsorbing $\mathrm{O}_{2}$ to form $-\mathrm{OOH}$ which can react with $\mathrm{CO}$ to form $\mathrm{CO}_{2}$, recovering surface hydroxyls [89]. The beneficial effect of surface hydroxyls in facilitating $\mathrm{CO}$ oxidation over $\mathrm{Au} / \mathrm{SiO}_{2}$ was also reported by $\mathrm{Wu}$ et al. [98]. Although here we do not have clear and direct evidence to show how surface hydroxyls are involved in the reaction mechanism and how surface basic sites may promote the reaction in our case, the correlation between surface hydroxyls/basicity and catalytic activity is clear. We hope that future studies can address these points employing more advanced methods, such as DFT calculation, kinetics studies, and isotope-labeling experiments.

It should be noted that Pt/La-P-O has a larger surface area, more basic sites, and higher Pt content than Pt/Ca-P-O (see Table 1), but its activity is significantly lower. We believe that this is due to two factors. First, as shown in Figure 6, Pt/La-P-O has a desorption peak centered at $257{ }^{\circ} \mathrm{C}$ whereas $\mathrm{Pt} / \mathrm{Ca}-\mathrm{P}-\mathrm{O}$ has a main desorption peak centered at $204{ }^{\circ} \mathrm{C}$. The amounts of basic sites are 147.9 and $76.8 \mu \mathrm{mol} / \mathrm{g}$, respectively. That means that $\mathrm{Pt} / \mathrm{La}-\mathrm{P}-\mathrm{O}$ not only has more basic sites than $\mathrm{Pt} / \mathrm{Ca}-\mathrm{P}-\mathrm{O}$, its basic strength is stronger than that of $\mathrm{Pt} / \mathrm{Ca}-\mathrm{P}-\mathrm{O}$. Too strong and too many basic sites of Pt/La-P-O may make the desorption of $\mathrm{CO}_{2}$ (produced by $\mathrm{CO}$ oxidation) difficult. As a rule of thumb in heterogeneous catalysis, too strong adsorption of the reactant/intermediate/product usually lowers the activity in catalysis [1]. Second, the hydroxyl level of Pt/La-P-O (8.8\% among all surface oxygen species) is significantly lower than that of Pt/Ca-P-O (37.9\%, see Table 1).

Although here we chose $\mathrm{CO}$ oxidation as a probe reaction, we believe than the newly developed $\mathrm{Pt} / \mathrm{M}-\mathrm{P}-\mathrm{O}$ catalysts may be useful in other reactions. From the examples cited in the Introduction section, it can be predicted that the most probable field the Pt/M-P-O catalysts can be useful is organic 
catalysis because Pt can catalyze hydrogenation/dehydrogenation reactions, whereas different metal phosphates have different acid-base properties and hydroxyapatite also has rich hydroxyls. The combination of both functionalities furnished by both Pt and M-P-O supports can make the catalysts be useful in organic catalysis and other reactions. This should be studied in more details in the future.

\section{Experimental Section}

\subsection{Synthesis of Catalysts}

$\mathrm{H}_{2} \mathrm{PtCl}_{6} \cdot 6 \mathrm{H}_{2} \mathrm{O}$ (Sinopharm Chemical Reagent, AR, Shanghai, China), $\mathrm{Mg}_{3}\left(\mathrm{PO}_{4}\right)_{2} \cdot \mathrm{xH}_{2} \mathrm{O}$ (Aldrich, $>98 \%$, Shanghai, China), AlPO 4 (Aladdin, CP, Shanghai, China), $\mathrm{Ca} 5(\mathrm{OH})\left(\mathrm{PO}_{4}\right)_{3}(\mathrm{~J} \& \mathrm{~K}$ Chemical, 96\%, Shanghai, China), FePO $\cdot \mathrm{xH}_{2} \mathrm{O}$ (Alfa Aesar, CP, Shanghai, China), $\mathrm{CoPO}_{4}$ (Alfa Aesar, 98\%), $\mathrm{Zn}_{3}\left(\mathrm{PO}_{4}\right)_{2}\left(\mathrm{~J} \& \mathrm{~K}\right.$ Chemical, CP), and $\mathrm{LaPO}_{4} \cdot \mathrm{xH}_{2} \mathrm{O}$ (Alfa Aesar, 99.99\%) were used as received. The $\mathrm{Pt} / \mathrm{M}-\mathrm{P}-\mathrm{O}$ catalysts were prepared by a conventional incipient wetness impregnation method. In a typical synthesis, $0.212 \mathrm{~g} \mathrm{H}_{2} \mathrm{PtCl}_{6} \cdot 6 \mathrm{H}_{2} \mathrm{O}$ was dissolved in $40-50 \mathrm{~mL}$ deionized water in a $250 \mathrm{~mL}$ beaker; $3.92 \mathrm{~g}$ M-P-O was then weighed and immersed into the aqueous solution at room temperature. The mixture was stirred gently using a glass rod and allowed to keep static overnight, and then dried in an oven at $80{ }^{\circ} \mathrm{C}$ for $12 \mathrm{~h}$. The obtained solid was grid into powders and divided into two parts which were then calcined in a muffle oven under static air at 300 or $500{ }^{\circ} \mathrm{C}$, respectively, for $2 \mathrm{~h}$.

\subsection{Characterization}

XRD experiments involving spent Pt/M-P-O catalysts (calcined at 300 or $500{ }^{\circ} \mathrm{C}$, pretreated in $4 \%$ $\mathrm{H}_{2}$ at $300{ }^{\circ} \mathrm{C}$, and then tested in $\mathrm{CO}$ oxidation) and M-P-O supports calcined at $500{ }^{\circ} \mathrm{C}$ (for reference) were conducted on a PW3040/60X'Pert PRO X-ray diffractometer (PANalytical, Almelo, Netherlands) with $\mathrm{Cu} \mathrm{K \alpha}$ radiation at $40 \mathrm{kV}$ and $40 \mathrm{~mA}$. The scanning was conducted at $2 \theta=20-90^{\circ}$, and the scanning rate was $6 \%$ min.

The specific surface areas (SBET) of Pt/M-P-O calcined at $500{ }^{\circ} \mathrm{C}$ were determined from nitrogen adsorption-desorption isotherms measured at $-196{ }^{\circ} \mathrm{C}$ using a Micromeritics ASAP $2020 \mathrm{M}+\mathrm{C}$ surface area and porosity analyzer (Micromeritics, Norcross, GA, USA). Before the measurement, a sample $(0.1-0.2 \mathrm{~g})$ was degassed at $200{ }^{\circ} \mathrm{C}$ for $6 \mathrm{~h}$, the weight of the sample was measured again, and the sample was then subjected to $\mathrm{N}_{2}$ adsorption-desorption.

ICP analyses of Pt/M-P-O catalysts calcined at $500{ }^{\circ} \mathrm{C}$ were conducted using a Model-P4010 instrument (Hitachi, Tokyo, Japan) after dissolution of the samples in aqua regia and appropriate dilution.

TEM experiments involving spent Pt/M-P-O catalysts (calcined at 300 or $500{ }^{\circ} \mathrm{C}$, pretreated in $4 \%$ $\mathrm{H}_{2}$ at $300{ }^{\circ} \mathrm{C}$, and then tested in CO oxidation) were conducted on a JOEL JEM2100F field-emission transmission electron microscope (JOEL Ltd., Tokyo, Japan) with acceleration voltage of $200 \mathrm{kV}$. Prior to recording TEM images, a small portion of sample was dispersed in ethanol, and a few drops were dropped onto a $\mathrm{Cu}$ grid-supported carbon film and dried under an infrared lamp.

$\mathrm{CO}_{2}$-TPD experiments involving Pt/M-P-O catalysts (calcined at $500{ }^{\circ} \mathrm{C}$, pretreated in $4 \% \mathrm{H}_{2}$ at $300{ }^{\circ} \mathrm{C}$ ) were performed in a FINESORB-3010 temperature-programmed chemsorber (FINETEC, Hangzhou, China). A catalyst (0.25 g, 40-60 mesh) was loaded into a U-shaped glass tube, 4\% $\mathrm{H}_{2}$ (balance $\mathrm{He}$, total flow rate $50 \mathrm{~mL} / \mathrm{min}$ ) was then used to sweep the catalyst, and the temperature was 
ramped from room temperature to $300{ }^{\circ} \mathrm{C}$ (at a rate of $10{ }^{\circ} \mathrm{C} / \mathrm{min}$ ) in the presence of flowing $4 \% \mathrm{H}_{2}$, and kept at $300{ }^{\circ} \mathrm{C}$ for $2 \mathrm{~h}$. Then the catalyst was cooled to $50{ }^{\circ} \mathrm{C}$, and exposed to flowing $\mathrm{CO}_{2}$ $(40 \mathrm{~mL} / \mathrm{min})$ at $50{ }^{\circ} \mathrm{C}$ for $1 \mathrm{~h}$. The $\mathrm{CO}_{2}$ gas was then switched to $\mathrm{He}(40 \mathrm{~mL} / \mathrm{min})$ and swept by the $\mathrm{He}$ flow for $3 \mathrm{~h}$ to remove physically adsorbed $\mathrm{CO}_{2}$. The temperature was then ramped to $600{ }^{\circ} \mathrm{C}$ at a rate of $10{ }^{\circ} \mathrm{C} / \mathrm{min}$ to allow for the desorption of adsorbed $\mathrm{CO}_{2}$ under flowing $\mathrm{He}$.

XPS experiments involving spent Pt/M-P-O catalysts (calcined at $500{ }^{\circ} \mathrm{C}$, pretreated in $4 \% \mathrm{H}_{2}$ at $300{ }^{\circ} \mathrm{C}$, and then tested in $\mathrm{CO}$ oxidation) and additionally, $\mathrm{Pt} / \mathrm{Ca}-\mathrm{P}-\mathrm{O}$ calcined at $500{ }^{\circ} \mathrm{C}$ as well as $\mathrm{Pt} / \mathrm{Ca}-\mathrm{P}-\mathrm{O}$ calcined at $500{ }^{\circ} \mathrm{C}$ and pretreated in $4 \% \mathrm{H}_{2}$, were collected on a Perkin-Elmer PHI 5000C ESCA instrument (Perkin Elmer, Waltham, MA, USA), with $\mathrm{MgK} \alpha$ radiation source (voltage $14 \mathrm{kV}$, current $20 \mathrm{~mA}$ ). The binding energies were corrected by using the binding energy of $\mathrm{C} 1 \mathrm{~s}$ as a reference, and the XPS data were processed using XPS PEAK41 software.

$\mathrm{H}_{2}$-TPD experiments involving M-P-O supports calcined at $500{ }^{\circ} \mathrm{C}$ were conducted in a FINESORB-3010 temperature-programmed chemsorber (FINETEC, Hangzhou, China). A sample (0.12 g, 40-60 mesh) was loaded into a U-shaped glass tube, and the sample was then heated from room temperature to $50{ }^{\circ} \mathrm{C}$ at a rate of $10{ }^{\circ} \mathrm{C} / \mathrm{min}$ under the protection of flowing He. The gas was then switched to $10 \% \mathrm{H}_{2}$ (balance Ar, total flow rate $30 \mathrm{~mL} / \mathrm{min}$ ), and the sample was swept by $10 \% \mathrm{H}_{2}$ for $3 \mathrm{~h}$. Finally, the temperature was ramped from 50 to $800{ }^{\circ} \mathrm{C}$, and $10 \% \mathrm{H}_{2}$ was still flowing at a rate of $30 \mathrm{~mL} / \mathrm{min}$.

\subsection{Catalytic Testing}

A catalyst $(0.25 \mathrm{~g})$ was loaded into a U-shaped glass tube, sealed by quartz wools on both sides of the catalyst zone, and the U-shaped glass tube was then put in a fixed bed reactor (FINESORB-3010 temperature-programmed chemsorber, FINETEC, Hangzhou, China), and 4\% $\mathrm{H}_{2}$ (balance $\mathrm{He}$ ) was flowed through the catalyst at a rate of $50 \mathrm{~mL} / \mathrm{min}$. The catalyst was heated to $300{ }^{\circ} \mathrm{C}$ at a rate of $10{ }^{\circ} \mathrm{C} / \mathrm{min}$, and kept at $300{ }^{\circ} \mathrm{C}$ for $2 \mathrm{~h}$, while the $4 \% \mathrm{H}_{2}$ was still flowing. After the catalyst was cooled down to room temperature, the gas stream was switched to $1 \% \mathrm{CO}$ (in air, flow rate: $50 \mathrm{~mL} / \mathrm{min}$ ). The catalyst was maintained at room temperature for $1 \mathrm{~h}$, and then heated to $300{ }^{\circ} \mathrm{C}$ at a rate of $0.5{ }^{\circ} \mathrm{C} / \mathrm{min}$, while the $1 \% \mathrm{CO}$ was still flowing at a rate of $50 \mathrm{~mL} / \mathrm{min}$. The space velocity was $12,000 \mathrm{~cm}^{3} /\left(\mathrm{h} \cdot \mathrm{g}_{\mathrm{cat}}\right)$. The exiting stream was continuously analyzed by GC (Agilent $\left.7890 \mathrm{~A}\right)$. The CO conversion was calculated as $\left[\mathrm{CO}_{2}\right]_{\text {out }} /\left([\mathrm{CO}]_{\text {out }}+\left[\mathrm{CO}_{2}\right]_{\text {out }}\right)$.

\section{Conclusions}

A series of metal phosphate-supported Pt catalysts (Pt/M-P-O, M = Mg, Al, Ca, Fe, Co, Zn, La) were developed and tested for $\mathrm{CO}$ oxidation. The catalysts calcined at $300{ }^{\circ} \mathrm{C}$ and pretreated in $4 \% \mathrm{H}_{2}$ at $300{ }^{\circ} \mathrm{C}$ can achieve complete $\mathrm{CO}$ oxidation at $100-140{ }^{\circ} \mathrm{C}$, whereas the catalyst calcined at $500{ }^{\circ} \mathrm{C}$ and pretreated in $4 \% \mathrm{H}_{2}$ at $300{ }^{\circ} \mathrm{C}$ can achieve complete $\mathrm{CO}$ oxidation at $80-210{ }^{\circ} \mathrm{C}$. The activity in the latter set of experiments follows the sequence of $\mathrm{Pt} / \mathrm{Ca}-\mathrm{P}-\mathrm{O}>\mathrm{Pt} / \mathrm{Co}-\mathrm{P}-\mathrm{O}>\mathrm{Pt} / \mathrm{Fe}-\mathrm{P}-\mathrm{O}>\mathrm{Pt} / \mathrm{La}-\mathrm{P}-\mathrm{O}>$ $\mathrm{Pt} / \mathrm{Mg}-\mathrm{P}-\mathrm{O}>\mathrm{Pt} / \mathrm{Al}-\mathrm{P}-\mathrm{O}>\mathrm{Pt} / \mathrm{Zn}-\mathrm{P}-\mathrm{O}$. The better activity of $\mathrm{Pt} / \mathrm{Ca}-\mathrm{P}-\mathrm{O}$ is not only related to the small Pt nanoparticles (2-3 nm) on Ca-P-O, but also linked to the basicity and rich hydroxyls on the support, as proved by $\mathrm{CO}_{2}$-TPD and XPS characterization. In addition, XPS data demonstrate that the pretreatment of $\mathrm{Pt} / \mathrm{Ca}-\mathrm{P}-\mathrm{O}$ in $4 \% \mathrm{H}_{2}$ can reduce $\mathrm{Pt}^{4+}$, remove a small portion of residual $\mathrm{Cl}$, and enrich 
the hydroxyls. These effects are beneficial for enhancing the activity in $\mathrm{CO}$ oxidation. Although here we chose $\mathrm{CO}$ oxidation as a probe reaction, we believe than the newly developed Pt/M-P-O catalysts may find applications in other reactions, considering the functionality furnished by both $\mathrm{Pt}$ and M-P-O supports.

\section{Supplementary Materials}

Supplementary materials can be accessed at: http://www.mdpi.com/1996-1944/7/12/8105/s1.

\section{Acknowledgments}

Zhen Ma acknowledges the financial support by National Natural Science Foundation of China (Grant No. 21177028) and the Overseas Returnees Start-Up Research Fund of the Ministry of Education in China.

\section{Author Contributions}

Xiaoshuang Qian and Hongmei Qin conducted all of the synthesis and the catalytic testing. Tao Meng and Yi Lin did the XRD characterization. Tao Meng helped maintain the catalytic testing apparatus. Zhen Ma guided the TEM characterization. Xiaoshuang Qian and Zhen Ma interpreted the results and wrote the manuscript. All contributed to the discussions.

\section{Conflicts of Interest}

The authors declare no conflict of interest.

\section{References}

1. Ma, Z.; Zaera, F. Heterogeneous catalysis by metals. In Encyclopedia of Inorganic and Bioinorganic Chemistry; Scott, R.A., Ed.; John Wiley \&Sons: Chichester, West Sussex, UK, 2014; eibc0079, pp. 1-16.

2. Ma, Z.; Tao, F. Metal salt-based gold nanocatalysts. In Metal Nanoparticles for Catalysis: Advances and Applications; Tao, F., Ed.; the Royal Society of Chemistry: London, UK, 2014; pp. 157-171.

3. Tanabe, K.; Misono, M.; Ono, Y.; Hattori, H. New Acid and Bases; Elsevier: Amsterdam, The Netherlands, 1989.

4. Takita, Y.; Yamashita, H.; Moritaka, K. Selective partial oxidation of propane over metal phosphate catalysts. Chem. Lett. 1989, 18, 1733-1736.

5. Takita, Y.; Sano, K.; Kurosaki, K.; Kawata, N.; Nishiguchi, H.; Ito, M.; Ishihara, T. Oxidative dehydrogenation of iso-butane to iso-butene-I. Metal phosphate catalysts. Appl. Catal. A 1998, 167, 49-56.

6. Takita, Y.; Sano, K.; Muraya, T.; Nishiguchi, H.; Kawata, N.; Ito, M.; Akbay, T.; Ishihara, T. Oxidative dehydrogenation of iso-butane to iso-butene-II. Rare earth phosphate catalysts. Appl. Catal. A 1998, 170, 23-31. 
7. Takita, Y.; Qing, X.; Takami, A.; Nishiguchi, H.; Nagaoka, K. Oxidative dehydrogenation of isobutane to isobutene-III. Reaction mechanism over CePO4. Appl. Catal. A 2005, 296, 63-69.

8. Bautista, F.M.; Campelo, J.M.; Luna, D.; Marinas, J.M.; Quirós, R.A.; Romero, A.A. Screening of amorphous metal-phosphate catalysts for the oxidative dehydrogenation of ethylbenzene to styrene. Appl. Catal. B 2007, 70, 611-620.

9. Johnstone, R.A.W.; Liu, J.Y.; Whittaker, D. Mechanism of cyclohexanol dehydration catalysed by zirconium phosphate. J. Chem. Soc. Perkin Trans. 1998, 2, 1287-1288.

10. Costa, M.C.C.; Hodson, L.F.; Johnstone, R.A.W.; Liu, J.Y.; Whittaker, D. The mechanism of gas-phase dehydration of cyclohexanol and the methylcyclohexanols catalysed by zirconium phosphate. J. Mol. Catal. A 1999, 142, 349-360.

11. Johnstone, R.A.W.; Liu, J.Y.; Whittaker, D. Mechanism of heterogeneous gas phase dehydration of 1-methylcyclohexanol catalysed by metal(IV) phosphates. J. Mol. Catal. A 2001, 174, $159-168$.

12. Al-Qallaf, F.A.H.; Johnstone, R.A.W.; Liu, J.Y.; Lu, L.; Whittaker, D. Metal(IV) phosphate catalyzed retro-Prins reaction involving an oxetane intermediate. J. Chem. Soc. Perkin Trans. 1999, 2, 1421-1423.

13. Al-Qallaf, F.A.H.; Hodson, L.F.; Johnstone, R.A.W.; Liu, J.Y.; Lu, L.; Whittaker, D. Heterogeneous liquid phase catalysis by metal (IV) phosphates of cyclic ether formation and a reverse Prins reaction. J. Mol. Catal. A 2000, 152, 187-200.

14. Costa, M.C.C.; Johnstone, R.A.W.; Whittaker, D. Catalysis of terpene rearrangements by zirconium phosphates and zirconium organo-substituted phosphonates. J. Mol. Catal. A 1998, 129, 79-89.

15. Costa, M.C.C.; Johnstone, R.A.W.; Whittaker, D. Properties of polymeric zirconium phosphates as Friedel-Crafts catalysts. J. Mol. Catal. A 1995, 103, 155-162.

16. Li, G.L.; Ishihara, T.; Nishiguchi, H.; Moro-oka, Y.; Takita, Y. Novel catalysts effective for dehydrofluorination of $\mathrm{CH}_{3} \mathrm{CH}_{3}$ (HFC143a) into $\mathrm{CF}_{2} \mathrm{CH}_{2}$. Chem. Lett. 1996, 507-508.

17. Li, G.L.; Nishiguchi, H.; Ishihara, T.; Moro-oka, Y.; Takita, Y. Catalytic dehydrofluorination of $\mathrm{CF}_{3} \mathrm{CH}_{3}\left(\mathrm{HFC143a}\right.$ ) into $\mathrm{CF}_{2} \mathrm{CH}_{2}$ (HFC1132a). Appl. Catal. B 1998, 16, 309-317.

18. Takita, Y.; Ninomiya, M.; Matsuzaki, R.; Wakamatsu, H.; Nishiguchi, H.; Ishihara, T. Decomposition of chlorofluorocarbons over metal phosphate catalysts-Part I. Decomposition of $\mathrm{CCl}_{2} \mathrm{~F}_{2}$ over metal phosphate catalysts. Phys. Chem. Chem. Phys. 1999, 1, 2367-2373.

19. Takita, Y.; Wakamatsu, H.; Li, G.L.; Moro-oka, Y.; Nishiguchi, H.; Ishihara, T. Decomposition of chlorofluorocarbons over metal phosphate catalysis-II. Origin of the stability of $\mathrm{AlPO}_{4}$ and the location of Ce as a promoter. J. Mol. Catal. A 2000, 155, 111-119.

20. Takita, Y.; Moriyama, J.I.; Yoshinaga, Y.; Nishiguchi, H.; Ishihara, T.; Yasuda, S.; Ueda, Y.; Kubo, M.; Miyamoto, A. Adsorption of water vapor on the AlPO4-based catalysts and reaction mechanism for CFCs decomposition. Appl. Catal. A 2004, 271, 55-60.

21. Takita, Y.; Morita, C.; Ninomiya, M.; Wakamatsu, H.; Nishiguchi, H.; Ishihara, T. Catalytic decomposition of $\mathrm{CF}_{4}$ over $\mathrm{AlPO}_{4}$-based catalysts. Chem. Lett. 1999, 417-418.

22. Takita, Y.; Ninomiya, M.; Miyake, H.; Wakamatsu, H.; Yoshinaga, Y.; Ishihara, T. Catalytic decomposition of perfluorocarbons-Part II. Decomposition of $\mathrm{CF}_{4}$ over $\mathrm{AlPO}_{4}$-rare earth phosphate catalysts. Phys. Chem. Chem. Phys. 1999, 1, 4501-4504. 
23. Takita, Y.; Tanabe, T.; Ito, M.; Ogura, M.; Muraya, T.; Yasuda, S.; Nishiguchi, H.; Ishihara, T. Decomposition of $\mathrm{CH}_{2} \mathrm{FCF}_{3}$ (134a) over metal phosphate catalysts. Ind. Eng. Chem. Res. 2002, $41,2585-2590$.

24. Takita, Y.; Sadatomi, Y.; Nishiguchi, H.; Nagaoka, K. Decomposition of chlorobenzene over phosphate and sulphate catalysts properties. Bull. Chem. Soc. Jpn. 2006, 79, 145-148.

25. Kashiwagi, D.; Takai, A.; Takubo, T.; Nagaoka, K.; Inoue, T.; Takita, Y. Metal phosphate catalysts efficient for degradation of sulfur hexafluoride. Ind. Eng. Chem. Res. 2009, 48, 632-640.

26. Kashiwagi, D.; Takita, A.; Takubo, T.; Yamada, H.; Inoue, T.; Nagaoka, K.; Takita, Y. Catalytic activity of rare earth phosphates for $\mathrm{SF}_{6}$ decomposition and promotion effects of rare earths added in AlPO4. J. Colloid Interface Sci. 2009, 332, 136-144.

27. Takubo, T.; Hirose, Y.; Kashiwagi, D.; Inoue, T.; Yamada, H.; Nagaka, K.; Takita, Y. Metal phosphate and fluoride catalysts active for hydrolysis of NF3. Catal. Commun. 2009, 3, 147-150.

28. Lisnyak, V.V.; Ischenko, E.V.; Stratiichuk, D.A.; Zaderko, A.N.; Boldyrieva, Q.Yu.; Safonova, V.V.; Yatsymyrskyi, A.V. Pt, Pd supported on niobium phosphates as catalysts for the hydrogen oxidation. Res. J. Chem. Sci. 2013, 3, 30-33.

29. Johnstone, R.A.W.; Liu, J.Y.; Lu, L.; Whittaker, D. Hydrogenation of alkenes over palladium and platinum metals supported on a variety of metal(IV) phosphates. J. Mol. Catal. A 2003, 191, 289-294.

30. Danjo, Y.; Kikuchi, I.; Ino, Y.; Ohshima, M.; Kurokawa, H.; Miura, H. Support effect of $\mathrm{Pd} / \mathrm{AlPO}_{4}$ catalyst in hydrogen storage of organic hydride method in the presence of CO. React. Kinet. Mech. Catal. 2012, 105, 381-389.

31. Takita, Y.; Ohkuma, T.; Nishiguchi, H.; Nagaoka, K.; Nakajo, T. Novel tough catalyst supports for reactions involving HF. Appl. Catal. A 2005, 283, 47-52.

32. Yan, W.F.; Brown, S.; Pan, Z.W.; Mahurin, S.M.; Overbury, S.H.; Dai, S. Ultrastable gold nanocatalyst supported by nanosized non-oxide substrate. Angew. Chem. Int. Ed. 2006, 45, 3614-3618.

33. Ma, Z.; Yin, H.F.; Overbury, S.H.; Dai, S. Metal phosphates as a new class of supports for gold nanocatalysts. Catal. Lett. 2008, 126, 20-30.

34. Ma, Z.; Yin, H.F.; Dai, S. Influence of preparation methods on the performance of metal phosphate-supported gold catalysts in CO oxidation. Catal. Lett. 2010, 138, 40-45.

35. Li, M.J.; Wu, Z.L.; Ma, Z.; Schwartz, V.; Mullins, D.R.; Dai, S.; Overbury, S.H. CO oxidation on $\mathrm{Au} / \mathrm{FePO}_{4}$ catalyst: Reaction pathways and nature of Au sites. J. Catal. 2009, 266, 98-105.

36. Li, M.J.; Wu, Z.L.; Overbury, S.H. CO oxidation on phosphate-supported Au catalysts: Effect of support reducibility on surface reactions. J. Catal. 2011, 278, 133-142.

37. Zhang, D.L.; Zhao, H.W.; Zhao, X.Y.; Liu, Y.M.; Chen, H.; Li, X.J. Application of hydroxyapatite as catalyst and catalyst carrier. Prog. Chem. 2011, 23, 687-694.

38. Tsuchida, T.; Sakuma, S.; Takeguchi, T.; Ueda, W. Direct synthesis of $n$-butanol from ethanol over nonstoichiometric hydroxyapatite. Ind. Eng. Chem. Res. 2006, 45, 8634-8642.

39. Tsuchida, T.; Yoshioka, T.; Sakuma, S.; Takeguchi, T.; Ueda, W. Synthesis of biogasoline from ethanol over hydroxyapatite catalyst. Ind. Eng. Chem. Res. 2008, 47, 1443-1452.

40. Tsuchida, T.; Kubo, J.; Yoshioka, T.; Sakuma, S.; Takeguchi, T.; Ueda, W. Reaction of ethanol over hydroxyapatite affected by Ca/P ratio of catalyst. J. Catal. 2008, 259, 183-189. 
41. Sebti, S.; Tahir, R.; Nazih, R.; Saber, A.; Boulaajai, S. Hydroxyapatite as a new solid support for the Knoevenagel reaction in heterogeneous media without solvent. Appl. Catal. A 2002, 228, 155-159.

42. Mallouk, S.; Bougrin, K.; Laghzizil, A.; Benhida, R. Microwave-assisted and efficient solvent-free Knoevenagel condensation. A suitable protocol using porous calcium hydroxyapatite as catalyst. Molecules 2010, 15, 813-823.

43. Subramanian, M.; Vanangamudi, G.; Thirunarayanan, G. Hydroxyapatite catalyzed aldol condensation: Synthesis, spectral linearity, antimicrobial and inset antifeedant activities of some 2,5-dimethyl-3-furyl chalcones. Spectrochim. Acta A 2013, 110, 116-123.

44. Tahir, R.; Banert, K.; Sebti, S. Natural and synthetic phosphates: New and clean heterogeneous catalysts for the synthesis of 5-arylhydantoins. Appl. Catal. A 2006, 298, 261-264.

45. Zahouily, M.; Abrouki, Y.; Bahlaouan, B.; Rayadh, A.; Sebti, S. Hydroxyapatite: New efficient catalyst for the Michael addition. Catal. Commun. 2003, 4, 521-524.

46. Xu, J.; White, T.; Li, P.; He, C.H.; Han, Y.-F. Hydroxyapatite foam as a catalyst for formaldehyde combustion at room temperatue. J. Am. Chem. Soc. 2010, 132, 13172-13173.

47. Matsumura, Y.; Moffat, J.B.; Sugiyama, S.; Hayashi, H.; Shigemoto, N.; Saltoh, K. Selective oxidative coupling of methane catalyzed over hydroxyapatite ion-exchanged with lead. $J$. Chem. Soc. Faraday Trans. 1994, 90, 2133-2140.

48. Masuyama, Y.; Nakajima, Y.; Okabe, J. Environmentally-benign palladium(II)-exchanged hydroxyapatite-catalyzed allylic alkylation of allyl methyl carbonate in water. Appl. Catal. A 2010, 387, 107-112.

49. Masuyama, Y.; Sugioka, Y.; Chonan, S.; Suzuki, N.; Fujita, M.; Hara, K.; Fukuoka, A. Palladium(II)-exchanged hydroxyapatite-catalyzed Suzuki-Miyaura-type cross-coupling reactions with potassium aryltrifluoroborates. J. Mol. Catal. A 2013, 352, 81-85.

50. Saha, D.; Chatterjee, T.; Mukherjee, M.; Ranu, B. Copper(I) hydroxyapatite catalyzed Sonogashira reaction of alkynes with styrenyl bromides. Reaction of cis-styrenyl bromides forming unsymmetric diynes. J. Org. Chem. 2012, 77, 9379-9383.

51. Maaten, B.; Moussa, J.; Desmarets, C.; Gredin, P.; Beaunier, P.; Kanger, T.; Tõnsuaadu, K.; Villemin, D.; Gruselle, M. Cu-modified hydroxyl-apatite as catalyst for Glaser-Hay C-C homo-coupling reaction of terminal alkynes. J. Mol. Catal. A 2014, 393, 112-116.

52. Qu, Z.P.; Sun, Y.H.; Chen, D.; Wang, Y. Possible sites of copper located on hydroxyalatites structure and the identification of active sites for formaldehyde oxidation. J. Mol. Catal. A 2014, 393, 182-190.

53. Low, H.R.; Avdeev, M.; Ramesh, K.; White, T.J. Zinc hydroxyapatite catalyst for decomposition of 2-propanol. Adv. Mater. 2012, 24, 4175-4179.

54. Neelakandeswari, N.; Sangami, G.; Emayavaramban, P.; Karvembu, R.; Dharmaraj, N.; Kim, H.Y. Mesoporous nickel hydroxyapatite nanocomposite for microwave-assisted Henry reaction. Tetrahedron Lett. 2012, 53, 2980-2984.

55. Ogo, S.; Onda, A.; Yanagisawa, K. Hydrothermal synthesis of vanadate-substituted hydroxyapatites, and catalytic properties for conversion of 2-propanol. Appl. Catal. A 2008, 348, 129-135.

56. Carniti, P.; Gervasini, A.; Tiozzo, C.; Guidotti, M. Niobium-containing hydroxyapatites as amorphous catalysts: synthesis, properties, and activity. ACS Catal. 2014, 4, 469-479. 
57. Ogo, S.; Onda, A.; Iwasa, Y.; Hara, K.; Fukuoka, A.; Yanagisawa, K. 1-Butanol synthesis from ethanol over strontium phosphate hydroxyapatite catalysts with various $\mathrm{Sr} / \mathrm{P}$ ration. J. Catal. 2012, 296, 24-30.

58. Venugopal, A.; Scurrell, M.S. Hydroxyapatite as a novel support for gold and ruthenium catalysts-Behavior in the water gas shift reaction. Appl. Catal. A 2003, 245, 137-147.

59. Phonthammachai, N.; Zhong, Z.Y.; Guo, J.; Han, Y.F.; White, T.J. Synthesis of high performance hydroxyapatite-gold catalysts for CO oxidation. Gold Bull. 2008, 41, 42-50.

60. Domínguez, M.I.; Romero-Sarria, F.; Centeno, M.A.; Odriozola, J.A. Gold/hydroxyapatite catalysts: Synthesis, characterization and catalytic activity to CO oxidation. Appl. Catal. B 2009, 87, 245-251.

61. Huang, J.; Wang, L.-C.; Liu, Y.-M.; Cao, Y.; He, H.-Y.; Fan, K.-N. Gold nanoparticles supported on hydroxyapatite as high performance catalysts for low temperature $\mathrm{CO}$ oxidation. Appl. Catal. B 2011, 101, 560-569.

62. Zhao, K.F.; Qiao, B.T.; Wang, J.H.; Zhang, Y.J.; Zhang, T. A highly active and sintering-resistant $\mathrm{Au} / \mathrm{FeO}_{\mathrm{x}}$-hydroxyapatite catalyst for $\mathrm{CO}$ oxidation. Chem. Commun. 2011, 47, 1779-1781.

63. Mikami, Y.; Noujima, A.; Mitsudome, T.; Mizugaki, T.; Jitsukawa, K.; Kaneda, K. Highly efficient gold nanoparticle catalyzed deoxygenation of amides, sulfoxides, and pyridine $\mathrm{N}$-oxides. Chem. Eur. J. 2011, 17, 1768-1772.

64. Liu, Y.M.; Tsunoyama, H.; Akita, T.; Xie, S.H.; Tsukuda, T. Aerobic oxidation of cyclohexane catalyzed by size-controlled Au clusters on hydroxyapatite: Size effect in the sub-2 $\mathrm{nm}$ regime. ACS Catal. 2011, 1, 2-6.

65. Sun, H.; Su, F.-Z.; Ni, J.; Cao, Y.; He, H.Y.; Fan, K.N. Gold supported on hydroxyapatite as a versatile multifunctional catalyst for the direct tandem synthesis of imines and oximes. Angew. Chem. Int. Ed. 2009, 48, 4390-4393.

66. Han, Y.-F.; Phonthammachai, N.; Ramesh, K.; Zhong, Z.Y.; White, T. Removing organic compounds from aqueous medium via wet peroxidation by gold catalysts. Environ. Sci. Technol. 2008, 42, 908-912.

67. Chambyal, O.S.; Paul, S.; Shamim, T.; Gupta, M.; Gupta, R.; Loupy, A. HAP-Pd(0): A highly efficient recyclable heterogeneous catalyst for the selective reduction of carbon-carbon double bond in $\alpha$,- $\beta$-unsaturated ketones. Synth. Commun. 2013, 43, 656-667.

68. Wuyts, S.; De Vos, D.E.; Verpoort, F.; Depla, D.; De Gryse, R.; Jacobs, P.A. A heterogeneous Ru-hydroxyapatite catalyst for mild racemization of alcohols. J. Catal. 2003, 219, 417-424.

69. Ho, C.-M.; Yu, W.-J.; Che, C.-M. Ruthenium nanoparticles supported on hydroxyapatite as an efficient and recyclable catalyst for cis-dihydroxylation and oxidative cleavage of alkenes. Angew. Chem. Int. Ed. 2003, 43, 3303-3307.

70. Durak, H.; Gulcan, M.; Zahmakiran, M.; Ozkar, S.; Kaya, M. Hydroxyapatite-nanosphere supported ruthenium(0) nanoparticle catalyst for hydrogen generation from ammonia-borane solution: Kinetic studies for nanoparticle formation and hydrogen evolution. RSC $A d v$. 2014, 4, 28947-28955.

71. Mitsudome, T.; Arita, S.; Mori, H.; Mizugaki, T.; Jitsukawa, K.; Kaneda, K. Supported silver-nanoparticle-catalyzed highly efficient aqueous oxidation of phenylsilanes to silanols. Angew. Chem. Int. Ed. 2008, 47, 7938-7940. 
72. Kumar, P.A.; Reddy, M.P.; Ju, L.K.; Phil, H.H. Novel silver loaded hydroxyapatite catalyst for the selective catalytic reduction of $\mathrm{NO}_{\mathrm{x}}$ by propene. Catal. Lett. 2008, 126, 78-83.

73. Haneda, M.; Watanabe, T.; Kamiuchi, N.; Ozawa, M. Effect of platinum dispersion on the catalytic activity of $\mathrm{Pt} / \mathrm{Al}_{2} \mathrm{O}_{3}$ for the oxidation of carbon monoxide and propene. Appl. Catal. B 2013, 142-143, 8-14.

74. Li, N.; Chen, Q.Y.; Luo, L.F.; Huang, W.X.; Luo, M.F.; Hu, G.S.; Lu, J.Q. Kinetic study and the effect of particle size on low temperature $\mathrm{CO}$ oxidation over $\mathrm{Pt} / \mathrm{TiO}_{2}$ catalysts. Appl. Catal. B 2013, 142-143, 523-532.

75. Kim, M.Y.; Choi, J.S.; Toops, T.J.; Jeong, E.S.; Han, S.W.; Schwartz, V.; Chen, J.H. Coating $\mathrm{SiO}_{2}$ support with $\mathrm{TiO}_{2}$ or $\mathrm{ZrO}_{2}$ and effects on structure and $\mathrm{CO}$ oxidation performance of Pt catalysts. Catalysts 2013, 3, 88-103.

76. Kamiuchi, N.; Haneda, M.; Ozawa, M. CO oxidation over $\mathrm{Pt} / \mathrm{Ce}-\mathrm{Zr}$ oxide catalysts with low content of platinum and cerium components. Catal. Today 2013, 201, 79-84.

77. Shen, M.Q.; Lv, L.F.; Wang, J.Q.; Zhu, J.X.; Huang, Y.; Wang, J. Study of Pt dispersion on Ce based supports and the influence on the CO oxidation reaction. Chem. Eng. J. 2014, 255, 40-48.

78. Chua, Y.P.G.; Gunasooriya, G.T.K.K.; Saeys, M.; Seebauer, E.G. Controlling the CO oxidation rate over $\mathrm{Pt} / \mathrm{TiO}_{2}$ catalysts by defect engineering of the $\mathrm{TiO}_{2}$ support. J. Catal. 2014, 311, 306-313.

79. Jung, C.H.; Yun, J.; Qadir, K.; Naik, B.; Yun, J.Y.; Park, J.Y. Catalytic activity of Pt/SiO 2 nanocatalysts synthesized via ultrasonic spray pyrolysis process under $\mathrm{CO}$ oxidation. Appl. Catal. B 2014, 154-155, 171-176.

80. An, N.H.; Yuan, X.L.; Pan, B.; Li, Q.L.; Li, S.Y.; Zhang, W.X. Design of a highly active Pt/Al ${ }_{2} \mathrm{O}_{3}$ catalyst for low-temperature CO oxidation. RSC Adv. 2014, 4, 38250-38257.

81. Oh, Y.; Kang, J.; Nam, S.; Byun, S.; Park, B. Pt/AlPO 4 nanocomposite thin-film electrodes for ethanol electrooxiadtion. Mater. Chem. Phys. 2012, 135, 188-192.

82. Park, J.; Oh, Y.; Park, Y.; Nam, S.; Moon, J.; Kang, J.; Jung, D.R.; Byun, S.; Park, B. Methanol oxidation in nanostructured platinum/cerium-phosphate thin films. Curr. App. Phys. 2011, 11, S2-S5.

83. Bouwman, P.J.; Dmowski, W.; Stanley, J.; Cotton, G.B.; Swider-Lyons, K.E. Platinum-iron phosphate electrocatalysts for oxygen reduction in PEMFCs. J. Electrochem. Soc. 2004, 151, A1989-A1998.

84. Lee, B.; Kim, C.; Park, Y.; Kim, T.G.; Park, B. Nanostructured platinum/iron phosphate thin film electrodes for methanol oxidation. Electrochem. Solid-State Lett. 2006, 9, E27-E30.

85. Gardner, S.D.; Hoflund, G.B.; Schryer, D.R.; Upchurch, B.T. Characterization study of silica-supported platinized tin oxide catalysts used for low-temperature $\mathrm{CO}$ oxidation: Effect of pretreatment temperature. J. Phys. Chem. 1991, 95, 835-838.

86. Lieske, H.; Lietz, G.; Spindler, H.; Völter, J. Reactions of platinum in oxygen- and hydrogen-treated $\mathrm{Pt} / \gamma-\mathrm{Al}_{2} \mathrm{O}_{3}$ catalysts: I. Temperature-programmed reduction, adsorption, and redispersion of platinum. J. Catal. 1983, 81, 8-16.

87. Gracia, F.J.; Miller, J.T.; Kropf, A.J.; Wolf, E.E. Kinetics, FTIR, and controlled atmosphere EXAFS study of the effect of chlorine on Pt-supported catalysts during oxidation reactions. J. Catal. 2002, 209, 341-354. 
88. Ma, Z.; Zaera, F. Characterization of heterogeneous catalysts. In Surface and Nanomolecular Catalysis; Richards, R., Ed.; Taylor \& Fransic: Boca Raton, FL, USA, 2006; pp. 1-37.

89. Chen, G.X.; Zhao, Y.; Fu, G.; Duchesne, P.N.; Gu, L.; Zheng, Y.P.; Weng, X.F.; Chen, M.S.; Zhang, P.; Pao, C.W.; Lee, J.F.; Zheng, N.F. Interfacial effects in iron-nickel hydroxide-platinum nanoparticles enhance catalytic oxidation. Science 2014, 344, 495-499.

90. Brow, R.K. An XPS study of oxygen bonding in zinc phosphate and zinc borophosphate glasses. J. Non-Cryst. Solids 1996, 194, 267-273.

91. Grosseau-Poussard, J.L.; Panicaud, B.; Pedraza, F.; Renault, P.O.; Silvain, J.F. Iron oxidation under the influence of phosphate thin films. J. Appl. Phys. 2003, 94, 784-788.

92. Mercado, D.F.; Magnacca, G.; Malandrino, M.; Rubert, A.; Montoneri, E.; Celi, L.; Prevot, A.B.; Gonzalez, M.C. Paramagnetic iron-doped hydroxyapatite nanoparticles with improved metal sorption properties. A bioorganic substrates-mediated synthesis. ACS Appl. Mater. Interfaces 2004, 6, 3937-3946.

93. Satterfield, C.N. Heterogeneous Catalysis in Industrial Practice, 2nd ed.; Krieger Publishing: Malabar, FL, USA, 1996; pp. 358-364.

94. Schubert, M.M.; Hackenberg, S.; van Veen, A.C.; Muhler, M.; Plzak, V.; Behm, R.J. CO oxidation over supported gold catalysts - "Inert" and "active" support materials and their role for the oxygen supply during reaction. J. Catal. 2001, 197, 113-122.

95. Weiher, N.; Bus, E.; Delannoy, L.; Louis, C.; Ramaker, D.E.; Miller, J.T.; van Bokhoven, J.A. Structure and oxidation state of gold on different supports under various $\mathrm{CO}$ oxidation conditions. J. Catal. 2006, 240, 100-107.

96. Lee, C.H.; Chen, Y.W. Effect of basic additives on $\mathrm{Pt} / \mathrm{Al}_{2} \mathrm{O}_{3}$ for $\mathrm{CO}$ and propylene oxidation under oxygen deficient conditions. Ind. Eng. Chem. Res. 1997, 36, 1498-1506.

97. Liu, X.J.; Wang, R.; Song, L.Y.; He, H.; Zhang, G.Z.; Zi, X.H.; Qiu, W.G. The oxidation of carbon monoxide over the palladium nanocube catalysts: Effect of the basic-property of the support. Catal. Commun. 2014, 46, 213-218.

98. Wu, Z.L.; Zhou, S.H.; Zhu, H.G.; Dai, S.; Overbury, S.H. DRIFTS-QMS study of room temperature $\mathrm{CO}$ oxidation on $\mathrm{Au} / \mathrm{SiO}_{2}$ catalyst: Nature and role of different Au species. J. Phys. Chem. C 2009, 113, 3726-3734.

(C) 2014 by the authors; licensee MDPI, Basel, Switzerland. This article is an open access article distributed under the terms and conditions of the Creative Commons Attribution license (http://creativecommons.org/licenses/by/4.0/). 